Ива Трифонова (София)

\title{
ОТКРОВЕНИЕ СВ. ИОАННА БОГОСЛОВА СРЕДИ ПРАВОСЛАВНЫХ СЛАВЯН И В ЮЖНОСЛАВЯНСКОЙ ПИСЬМЕННОСТИ
}

$O^{\prime}$ ткровение св. Иоанна Богослова (Апокалипсис) является единственной библейской пророческой книгой в составе Нового Завета и последней канонической книгой в корпусе христианской Библии. Она была написана, скорее всего, во время правления Домициана в конце I в. на острове Патмос в юго-восточной части Эгейского моря. Во II в. она получила широкое распространение и признание в греко- и латиноязычных молитвеных практиках, но потом, во время формирования состава Нового Завета, стала одной из самых обсуждаемых книг. Апокалипсис упоминается в числе канонических книг на Иппонском соборе 393 г. и на Карфагенском соборе 419 г. (33 правило). На Западе с признанием вдохновения и каноничности Откровения начинается и его богослужебное употребление, но среди отцов Восточной церкви споры продолжаются еще почти два столетия. В Римско-католической церкви уже с V-VI вв. тексты Откровения зачитывали на литургии в период между Пасхой и Пятидесятницей, а песнопения с мотивами из него вошли и в т. н. Литургию часов (ежедневный круг молитвенных богослужений). Для восточноправославного мира, наоборот, книга остается вне церковного богослужения. В православной литургической традиции имеется только воспоминание о Страшном суде за три недели до начала Великого поста, в так называемой Неделе Мясопустной (Неделе о Страшном суде), но в соответствии с евангельским текстом.

Таким образом, различное восприятие Откровения в западной и восточной литургической практике в значительной мере определяет дальнейшую судьбу книги: надо говорить как о западной, так и о восточной традиции восприятия и распространения данного текста. Поскольку Апокалипсис не входит в богослужебную практику восточной церкви, то его текст, в отличие от текста других книг Нового завета, засвидетельствован реже. Он обычно не был частью общего новозаветного корпуса, но входил в состав сборников разнородных текстов. Он также известен в ряде древних переводов и в разных цитатах из сочинений отцов церкви ${ }^{1}$.

\footnotetext{
${ }^{1}$ Более подробно cf. Иоанна Богослова Откровение, [in:] Православная энциклопедия, ed. Патриарх Московский и всея Руси Кирилл, vol. XXIV, Москва 2010, р. 705-745.
} 
Содержание Откровения св. Иоанна Богослова всегда смущает эсхатологической символикой и мистической образностью, которые давно перешли рамку богословского догматизма и исключительно церковного восприятия текста. И в латинской, и в византийской традиции популярны различные комментарии на эту книгу. Поскольку данное исследование фокусируется на византийской и славянской традиции, то следует отметить, что в византийской литературе были написаны только три полных комментария на Апокалипсис: Икумения, епископа Трикки во Фракии (IV в.), Андрея Кесарийского (между 563-614 гг.) и Арефы Кесарийского (ок. 850-после 932 гг.). В славянской рукописной традиции, равно как и в грузинской и армянской, были восприняты только толкования Андрея Кесарийского 2 .

Таким образом, в славянской православной письменности установились две греческие версии распространения Апокалипсиса: без толкований и с толкованиями св. Андрея Кесарийского. Рукописная традиция книги в славянском переводе, которая относится к Кирилло-Мефодиевскому наследию, имеет, однако, свои характерные особености.

Самый ранний сохранившийся список книги содержит толкования св. Андрея Кесарийского. Он датируется XIII в., написан на пергамене и имеет новгородские орфографические особенности (БАН, Санкт-Петербург, сб. Никольского 1 (N1) $)^{3}$. Существует много разных по происхождению списков книги XIV и XV вв., которые содержат различные версии текста. В некоторых из них сохраняется древнейший перевод, а в других - текст, содержащий поздние изменения. Это создает большие трудности при определении происхождения и истории различных версий Апокалипсиса. Поскольку он не входит в литургическую практику восточной церкви, до нас дошло не так много славянских списков Апокалипсиса, если сравнивать с библейскими книгами богослужебного пользования, таких как Евангелие, Псалтырь, Апостол.

Сохраненные списки книги XIV и XV вв. содержатся в сборниках, которые имеют различные функции. Эти списки отражают чтения, возникшие в разное время и на разных местах. Они или являлись частью различных типов средневековых составных книг, или представляли самостоятельные книги (в ее толковой версии). К традиции Slavia Orthodoxa, которая связывается с Кирилло-Мефодиевским переводческим наследием, относятся и те списки Апокалипсиса, которые находятся в составе хорватских богослужебных книг. Все это делает текстологическую картину изучения книги довольно сложной.

\footnotetext{
${ }^{2}$ M. De Groote, Oecumenii commentarius in Apokalypsin, Lovanii 1998 (= TEG 8); H. Hoskier, The Complete Commentary of Oecumenius on the Apocalypse, Ann Abor 1928; J. ScHмid, Der Apokalypsetext des Arethas von Kaisareia und einiger anderer jüngerer Gruppen, Athen 1936; Latin Commentaries on Revelation (Ancient Christian Texts), ed. et trans. W. WeINRICH, Downers Grove 2011.

${ }^{3}$ Смотри список сокращений рукописей.
} 
До недавнего времени внимание ученых было сосредоточено главным образом на описании и изучении двух групп списков: 1) Толковые списки XIII-XIX вв., которые обычно после XVI в. сопровождаются миниатюрами и сохранились главным образом среди восточных славян; 2) Боснийские списки и хорватские глаголические фрагменты ${ }^{4}$, которые сейчас считаются самыми ранними в текстологическом отношении списками. Только в последние два десятилетия научные исследования были направлены на обнаружение, систематизацию и изучение сохраненных южнославянских кириллических списков. Их немного, и они до сих пор не заняли свое достойное место в общей истории текста Апокалипсиса. Исследования этих списков имеют важное значение, они снова ставят вопросы о путях распространения Апокалипсиса среди восточных славян, потому что в введенных в научный оборот южнославянских списках содержится ряд древнейших особенностей. Их можно проследить на структурном, текстологическом и языковом уровнях, и таким образом переосмыслить существующие знания об истории Откровения в средневековых восточноправославных землях ${ }^{5}$.

Настоящее изложение сосредоточено на распространении Откровения св. Иоанна Богослова среди православных славян в средних веках и на обзоре существующих славянских версий книги. Поэтому я хотела бы поблагодарить сотрудников Хилендарской исследовательской библиотеки Информационного центра исследований славянского Средневековья в Университете штата Огайо (Колумбус, США), которые предоставили мне большую часть списков Апокалипсиса и часть необходимой научной литературы.

\footnotetext{
${ }^{4}$ V. OвLAк, Die kirchenslavische Übersetzung der Apokalypse, ASP 13, 1891, p. 321-361; I. BerčIĆ, Ulomci svetoga pisma obojega uvjeta staroslavenskim jezikom. Skupio iz rukopisa i tiskanih knjiga hrvatskoga razreda, vol. V, Praga 1866, p. 108-145; Ф.И. Буславв, Русскій тицевой апокалипсисъ. Свод изображений из тицевых апокалипсисов по рукописям с XVI-го века по XIX-ый, Москва 1884; Новый завпть господа нашето I. Христа, писанный рукою святителя Алексія митрополита всея Россіи, сфотографированньй въ 8-мь дней въ началю августу 1887 г. фотографомб Александромъ Андреевымъ Багнеровскимъ подъ непосредственнымъ наблюденіемг Даниловскаго Архимандрита Амфилохія; А.А. Алексевв, О.П. ЛихАчевА, К текстологической истории древнеславянского апокалипсиса, [in:] Материаль и сообщения по фондам Отдела рукописной и редкой книги БАН СССР 1985, ed. А.И. КоПАнЕв, Ленинград 1987, p. 8-22; K. GRÜNBERG, Die kirchenslavische Überlieferung der Johannes-Apokalypse, HPS.LR 9, Frankfurt am Main-Berlin-Bern-New York-Paris-Wien 1996; H. KunA, Zbornik Hvala krstjanina, vol. I, Faksimile, vol. II, Transkripcija i komentar, Sarajevo 1986.

${ }^{5}$ J. Грковић-Мејџор, Хиландарска апокалипса Јована Богослова (ХИЛ 474), ЈФ 56.1-2, 2000, p. 311-320; J. JurIć-KAPPEL, Bosanske apokalipse u svome (južno)slavenskom kontekstu, WSJ 48, 2002, p. 75-94; И. Трифонова, Южнославянската редакиия на Тълковния апокалипсис (Речник-индекс и издание на запазената част от Националната библиотека Св. Св. Кирил и Методий, Собия, № 101, XVI в.), Psl 22.1, 2014, p. 119-163.
} 


\section{Восточнославянская толковая редакция}

Надо заметить, что в восточнославянской литературной культуре особое место имеют списки с комментариями св. Андрея Кесарийского, а после XVI в. - с комментариями и миниатюрами (т.н. Лицевые Апокалипсисы). Эта версия книги обычно распространялась отдельно, в качестве самостоятельной книги. Она, как и оригинальный труд св. Андрея Кесарийского, состояла из 24 слов, 72 глав, 311 стихов. В начале стоит оглавление книги, затем следует содержание. Текст сегментирован на отдельные стихи, а после них следуют их толкования (Фиг. 1 и 2$)^{6}$. Списки в начале распространения книги содержали сокращенный вариант толкования св. Андрея Кесарийского. После сравнения с греческим текстом, наверное в XIV в., они были завершены, а после XVI в. они часто сопровождались и толкованиями других авторов. В текстологическом отношении библейский текст в индивидуальных списках стал в основном идентичным после публикации Острожской Библии 1580-81 гг., первого полного издания Библии на церковнославянском языке, и после издания толкового Апокалипсиса св. Андрея Кесарийского в 1625 г. в Киеве, в типографии Киево-Печерской лавры.

Ф. Буслаев в 1885 г. впервые описывает и классифицирует основные толковые версии текста Апокалипсиса, сопровождающиеся миниатюрами, XVI-XIX вв. Он разделяет списки на четыре основные группы, исходя из специфики текста и принципов создания миниатюр ${ }^{7}$. Своеобразным продолжением тематики является исследование истории иллюстрированных рукописей среди старообрядцев в XVIII-XIX вв. Н. Ануфриевой и И. Починской․ В 1995 г. был издан сборник Откровение св. Иоанна Богослова в мировой книжной традиции: Выставка9. Во вступительной части Г.В. Попов обращает внимание на значение сюжета Страшного суда в искусстве христианского мира и разделяет бытующее мнение, что Апокалипсис был переведен впервые св. Мефодием ${ }^{10}$. Он считает, что еще в X в. болгарские книжники перевели и толковую книгу на Апокалипсис св. Андрея Кесарийского, он также

\footnotetext{
${ }^{6}$ Илюстрации взяты с сайта Троице-Сергиевой лавры, http://old.stsl.ru/manuscripts/medium. php?col=1\&manuscript=119\&pagefile=119-0003, http://old.stsl.ru/manuscripts/medium.php?col= $1 \&$ manuscript $=119$ \&pagefile $=119-0007$ [11 XI 2016] .

${ }^{7}$ Ф.И. БУСЛАЕВ, op. cit.

${ }^{8}$ Н.В. АнуфриевА, И.В. ПочинскАя, Лищевые Апокалипсисы Урала: Православная традиция и элементы европейского культурного влияния, Екатеринбург 2014, p. 4-21.

${ }^{9}$ С.П. БАвин, Г.В. ПоПов, Откровение св. Иоанна Богослова в мировой книжной традииии: Выставка, Москва 1995.

${ }^{10}$ Характерно также и то, что именно тицезрение картин Страшного суда явилось переломным событием при „выборе веры” как болгарским князем Борисом в IX в. - соответственно сообщению Симона Логофета, так и столетие спустя великим киевским князем Владимиром
} 
отмечает факт, что сохранившихся южнославянских списков очень мало и что они без иллюстраций:

У южных славян Апокалипсис, судя по всему, не получил широкого распространения, несмотря на то большое значение, которое приобрели здесь эсхатологические сочинения как в эпоху византийского владычества XI-XII вв., когда даже события средневековой истории Болгарии осмыслялись местными книжниками в эсхатологическом ключе, так и при несомненном всплеске ожиданий конца света во времена османского завоевания Балкан во втор. пол. XIV-XV вв. ${ }^{11}$

Факт, что самый ранний сохранившийся список книги является восточнославянским толковым Апокалипсисом XIII в., содержащим новгородские орфографические особености, дает основание А. Алексееву и О. Лихачевой предположить, что в XII в. была сформирована традиция передачи комментированной версии книги среди восточных славян ${ }^{12}$. Как пишет ранее сам А. Алексеев,

отсутствие на славянском юге в XIV в. преславской традиции текста Св. Писания говорит о том, что на Русь она попала не в ходе миссионерской деятельности накануне или сразу после крещения Руси, а в составе библиотеки болгарских царей. Последняя, как известно, хранилась до поры в Преславе, а затем была целиком перенесена в Киев ${ }^{13}$.

Надо отметить тот факт, что Апокалипсис с толкованиями - это часть содержания Архивского хронографа ${ }^{14}$, который, как предполагается, в значительной степени отражает состав предполагаемой библиотеки болгарского царя Симеона (893-927 гг.), а, как хорошо известно, перевод библейских книг с комментариями в основном связан с деятельностью Преславского литературного центра.

- согласно „Повести временных лет” (Г.В. Попов, Апокалипсис в исскустве христианского мира, [in:] Откровение св. Иоанна Богослова..., p. 8).

11 Г.В. Попов, Рукописи древнерусские в старообрядческой традииии, [in:] Откровение св. Иоанна Богослова..., р. 28.

${ }^{12}$ А.А. АЛЕКСеЕв, О.П. ЛИХАЧЕвА, ор. cit., p. 20-21.

${ }^{13}$ И еще: До сих пор историческая гипотеза о судьбе преславской библиотеки основана была на том факте, что среди древнейших восточнославянских рукописей обнаружены непосредственные копии с экземпляров этой изарской библиотеки; имеются в виду Изборник 1073 (ГИМ, Син. 1043), Учительное евангелие Константина Болгарского (ГИМ, Син. 252), Слова Ипполита Римского об антихристе (ГИМ, Чуд. 12). Принадлежность оригиналов этих рукописей иарской библиотеке видна по включенным в них портретам изарей Симеона и Бориса-Михаила [...]. Как видно, текстологические особенности славянских библейских рукописей подтверждают эту историческую гипотезу (А.А. АлексеЕв, Текстология славянской библии, Санкт-Петербург 1999, р. 139).

${ }^{14}$ М. Оволенский, Летописеи, Переславля Суздальского, ВИМОИ 9, 1851, p. lix-lxii. 
Тексты Апокалипсиса без комментариев необычны для восточных славян. В основном они представлены Апокалипсисом Чудовского Нового завета середины XIV в. (С̆), и его позднейшими тремя копиями (T710, U310, $\mathrm{Tl})$, Апокалипсисом Геннадиевской Библии 1499 г. и текстом в Острожской Библии 1580-81 гг. Их следует выделить как отдельные редакции текста:

1. Чудовская редакиия Апокалипсиса. В тексте нет толкований, нет деления на главы, его вторично сравнивали с греческим образцом, и на каждом уровне он максимально приближен к греческому тексту. Уже доказано, что текст Евангелия и Псалтыри в Чудовской редакции особый, и что его можно сравнивать с афонской редакцией библейских книг середины XIV в. Его возникновение обусловлено литургическими реформами московского митрополита Алексея, связанными с переходом на Иерусалимский устав. На основе типикарского аппарата и текстологических особенностей Т. Пентковская предполагает, что

наличие целого ряда грецизмов, которых не было в древнейшем переводе Евангелия тетра и Апостола полного состава, типологически сближает Чудовскую редакцию Нового Завета с южнославянскими списками древнего текста XII-XIII вв. и указывает на возникновение архетипа Чудовской редакции в контактной византийско-славянской зоне ${ }^{15}$.

2. Апокалипсис в Геннадиевской Библии. Важен вывод А. Горского и К. Невоструева при описании рукописей Московской синодальной библиотеки, что текст Апокалипсиса в Геннадиевской Библии - это не новый перевод, а выводящийся из знакомой уже толковой версии книги. В нем сохраняется деление книги на 24 слова и 72 главы ${ }^{16}$. А как известно, Геннадиевская Библия является самым старым полным сводом библейских книг, имеющим большое значение для истории библейского текста среди славян. Отредактированный, тот же самый перевод стоит и в основе Апокалипсиса в Острожской Библии 1580-81 гг., Московской Библии 1663 г. и в Елизаветинской Библии 1751 г.

В 1987 г. в обзорной статье об истории текста Апокалипсиса на базе анализа 19 списков текста А. Алексеев и О. Лихачева обратили внимание на то, что перевод канонического текста книги и толкования на него могли бы иметь независимое происхождение и, по всей вероятности, различные текстологические традиции:

15 Т.В. ПЕнтковскАЯ, Чудовская редакиия Нового завета и ее взаимоотномение с другими редакциями, Pbg 27.3, 2003, p. 32.

${ }^{16}$ А.В. Горский, К.И. Невоструев, Описаніе Славянскихъ рукописей Московской синодальной библіотеки, Москва 1855, р. 157-160 (= MLSDV 2, 1964). В собрании рукописей Троице-Сергиевой лавры находятся еще два нетолковых текста Апокалипсиса XVI в. (№ 83 и № 84), в которых есть текст книги и содержание, оглавление, деление на 72 главы и 24 слова, а толкования удалены. Cf. http://old.stsl.ru/manuscripts/book.php?col=1\&manuscript=083, http://old. stsl.ru/manuscripts/book.php?col=1\&manuscript=084 [11 XI 2016]. 
Такое расхождение двух текстологических схем как будто бы исключает вопрос о южнославянском происхождении толкований, но оставляет открытым вопрос об их западнославянском (на чем настаивал Перетц) или восточнославянском происхождении. Стоит, однако, отметить, что текст Апокалипсиса, который был использвован переводчиком толкований, стоит в наибольшей близости к хорватскому глаголическому тексту ${ }^{17}$.

Особый интерес представляют исследования К. Грюнберга, автора самых объемных публикаций по этому вопросу, которые дают и стабильную текстологическую основу для будущих работ. Он пишет, что самые важные тексты для реконструкции истории Апокалипсиса - это боснийские тексты и редакция С̆, которым он посвятил свои анализы 1999 г. ${ }^{18}$ Он заметил, что очень вероятно боснийские списки, в которых есть деление на 72 главы и интерполяции из толковой версии книги, первоначально были толковыми, а потом толкования были вторично удалены, а текст версии С - результат поздней редакции славянского текста при сопоставлении с греческим оригиналом.

\section{Боснийская кириллическая редакция}

Эта редакция книги известна ученым давно. Она находится в боснийских богослужебных сборниках, а сам текст Апокалипсиса помещается после Евангелия и перед Апостолом. Она знакома по четырем рукописям XV и начала XVI вв.: 1) Апокалипсис Хвалового сборника 1404 г. (Hv); 2) Апокалипсис из Библиотеки Марциана в Венеции, XV в. (Ml); 3) Апокалипсис в Радосавлевом сборнике, где текст принят как основной, XV в., сегодня эта рукопись хранится в Ватиканской апостольской библиотеке в Риме (Rad); 4) Список, найденный в Супрасльском монастыре, 1507 г. (SSMD). Принято считать, что это самая древняя версия славянского текста Откровения. Интерес представляет тот факт, что в библейском тексте добавлено деление на 72 главы, знакомое из труда св. Андрея Кесарийского (Фиг. 3). В них есть и несколько интерполяций, которые, как уже известно, заимствованы тоже из толковой версии книги, но нет комментария, что является своеобразным отступлением от православной нормы ${ }^{19}$.

\footnotetext{
${ }^{17}$ А.А. АЛЕКСеЕВ, О.П. ЛиХАчевА, op. cit., p. 20.

${ }^{18}$ K. Grünberg, Die Apokalypse. Edition zweier Hyparchetypi, SSp 11, 1999; K. Grünberg, Zur lexikalischen Variation in der slavischen Überlieferung der Johannes-Apokalypse, [in:] Ars Philologica. Festschrift für Baldur Panzer zum 65. Geburtstag, ed. P. LANG, Frankfurt am Main-Berlin-BernBruxelles-New York-Wien 1999, p. 639-648.

${ }^{19}$ Как предположил J. НАмм, Apokalipsa bosanskih krstjana, Slo 9-10, 1960, p. 60.
} 
Текст Апокалипсиса из Хвалового сборника и особенности этой редакции исследовал впервые Д. Даничич ${ }^{20}$. В 1882 г. Ф. Рачки опубликовал текст из Радосавлевого сборника. Он обратил внимание на содержание рукописи и на наличие двух колофонов в тексте - кириллического и глаголического, - благодаря которым стали известными переписчик и датировка рукописи:

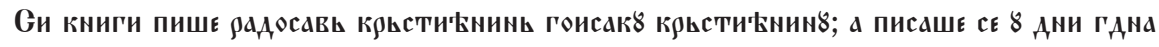

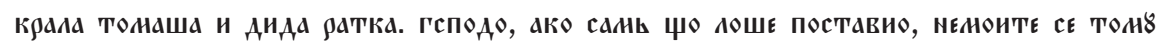

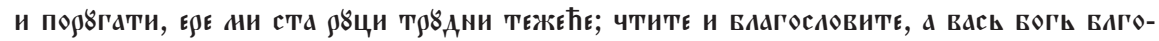
слови 8 вики аннь (л. 58$)^{21}$.

Ф. Рачки сопоставил содержание и расположение текстов в этой рукописи с Катарским требником из Лионской библиотеки и попытался найти связь между богослужениями боснийских патаренов и западных катаров ${ }^{22}$. В науке давно сложилось мнение, что Апокалипсис являлся одной из любимых книг богомилов. В своем исследовании 1957 г. Я. Шидак доказал, что по составу $\mathrm{Hv}$ и $\mathrm{Ml}$ одинаковы и обобщил мнения о характере Боснийской церкви на основе состава Hv, Ml и Rad - являлась ли она патаренской или православной:

Prema tome su već Rački i Daničić bili načistu s time, da se tekstovi Hvalova rukopisa s obzirom na svoj sadržaj i raspored ne razlikuju od novozavjetnih kniga u istočnoj crkvi, osim dvaju izuzetaka: mjesta, na kojem se nalazi Apokalipsa, i neobične pojave Dekaloga unutar tih knjiga. Rački je za prvi od tih izuzetka našao analogiju (ne istovjetnost!) u francuskih katara, a drugi je pokušao objasniti na svoj način kao jedan od znakova približavanija "Crkve bosanske" pravovjernom kršćanstvu ${ }^{23}$.

${ }^{20}$ Đ. DANIČIĆ, Hvalov rukopis, Star 3, 1871, p. 1-146; IDEM, Apokalypsa iz Hvalova rukopisa, Star 4, 1872, p. 86-109; Kako se iz kolofona vidi, pisan je 1404. god. za Hrvoja Vukčića Hrvatnića bosanskog vojvodu i vrlo značajnog feudalca tog vremena, koji je upravo tada dobio i naslov hercega grada Splita, te hrvatskodalmatinskog bana. On je, u stvari, u to doba namjestnik kralja Ladislava, koji se 1403. god. krunisao u Zadru za hrvatsko-ugarskog kralja. Za istog feudalcu istovremeno pisan je i poznati glagoljski Hrvojev misal. U kolofonu se pisar predstavio kao Hval kristjanin, što je direktno naznačenje pripadnosti crkvi bosanskih krstjana, a osim toga, kao što je običaj u bosanskim kodeksima, nominiran je i vjerski poglavica tog doba did Radomir. Iz teksta kolofona takođe je vidljivo da je kodeks pisan, najvjerovatnije, na jugozapadnijem tlu, tj. u Dalmatiji ili neposrednom zaleđu, sudeći bar po jezičkim pokazateljima kao to je upotreba termina 'мещзарьства' (H. KunA, op. cit., p. 12).

${ }^{21}$ F. RAČKI, Dva nova priloga za poviest bosanskih patarena, Star 4, 1882, p. 22; Он опубликовал и глаголическую запись на л. 59 в кириллической транслитерации: $\mathfrak{c}(\mathbf{в})$ павль апсль говори кь

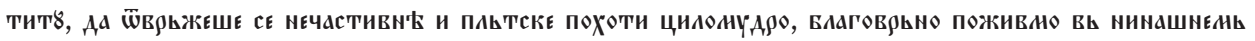

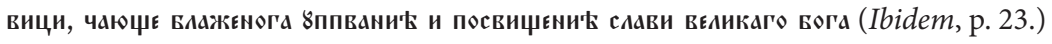

${ }^{22}$ Ibidem.

${ }^{23}$ J. ŠIDAK, Marginalija uz jedan rukopis "crkve bosanske" u Mletačkoj marciani, Slo 6-8, 1957, p. 141. 
В 1903 г. В. Ягич сравнил заглавия 72 глав в трех боснийских списках Hv, $\mathrm{Rad}$ и $\mathrm{Ml}$ и обнаружил, что они идентичны с заглавиями восточнославянской версии книги, несмотря на то, что близость между Hv и Rad гораздо больше, чем между $\mathrm{Hv}$ и $\mathrm{Ml}^{24}$.

В 1891 г. В. Облак сделал первое аналитическое исследование истории славянского перевода Апокалипсиса на основании публикаций $\mathrm{Hv}$, Rad и хорватских глаголических фрагментов Берчича. Он высказал мнение, что в основе этих текстов стоит один греческий оригинал, а следы латинского текста установились, наверное, позднее - благодаря западной редакции греческого текста. Он предположил, что перевод сделан не в самый ранний период славянской письменности, и в качестве места первого перевода принял Македонию, Афон или Боснию 25.

В 2002 г. в своей публикации о боснийских списках Откровения св. Иоанна, после обобщения существующих уже исследований, Я. Юрич-Капел вновь напомнила об особенностях вероятного славянского оригинала или оригиналов этой редакции, поскольку один из ее непосредственных источников был, наверное, глаголический, о чем говорят числовые ошибки и замены ера другими вокалами, на что обратил внимание Й. Хам:

Greške u bosanskim prepisima na koje je upozorovao Hamm (1960:52) načinjne, po njemu, zbog glagolične matice mogle su nastati samo pod utjecajem oble ili poluoble glagoljice. Još bitnijim argumentom koji bi govorio protiv neposredne veze između ovih grupa jeste postojanje tzv. „preslavskoga” leksičkog sloja u Vid, od kojega nema niti traga u bosanskima ${ }^{26}$.

На текст Апокалипсиса в Супрасльском сборнике 1507 г. как на важнейший для составления полного свода библейских книг без прямой зависимости от Геннадиевской Библии опыт впервые обратили внимание А. Алексеев и О. Лихачева. По их мнению, такой свод был приспособлен к монастырскому и церковному литургическому использованию. Они указали на сходства с Хваловой рукописью - и по местоположению Апокалипсиса в кодексе (после Евангелия и перед Апостолом), и по структурным особенностям текста. Авторы отметили, что часть разночтений возникла при ориентации на различные греческие списки, но определили общий первоисточник двух текстов, который не моложе XIII в., судя по незначительному количеству сербизмов $^{27}$. Связь этой рукописи с боснийскими списками имеет важное значение для определения культурных контактов между западнорусскими

${ }^{24}$ V. JAGIĆ, Analecta romana, ASP 25, 1903, p. 28.

${ }^{25} \mathrm{~V}$. OBLAK, op. cit.

${ }^{26}$ J. JURIĆ-KAPPEL, op. cit., p. 83.

${ }^{27}$ А.А. АЛЕКСеЕв, О.П. ЛиХАчевА, Супрасльский сборник 1507 г., [in:] Материалы и сообщения по фондам Отдела рукописной и редкой книги БАН СССР, ed. М.В. КукушкинА, Ленинград 1978 , p. 80-82. 
монастырями и сербским патриархом без зависимости от Москвы или Новгорода ${ }^{28}$. Сборник 1507 г. попал и в поле зрения И. Евсеева, который в 1912 г. писал:

Лучшимъ представителемъ, въ литовской Руси, библейскихъ переводовъ болгарского типа, уже обрусъвшихъ въ XV въкъ, является библейскій сводъ 1502-1507 года, т. наз. „Десятоглавъ Матвея Десятого"29.

\section{Сербская копия Апокалипсиса без толкований}

В 2000 г. Я. Гркович-Мейджор систематизировала известные до тех пор южнославянские списки Апокалипсиса и ввела в обращение научную информацию о самом раннем сохранившемся сербском списке книги ${ }^{30}$. Он является частью сборника последней четверти XIV в. с исихастскими и противолатинскими текстами из собрания Хилендарского монастыря № 474 (НM 474) (Фиг. 4)31. Она определила этот список как „старый тип”, с делением на 72 главы и без комментариев (в тексте написаны заглавия первых 5 глав, а остальные отмечены инициалом) $)^{32}$. Исследовательница связывает сербский список по типу и структуре с боснийскими списками и обращает внимание на тот факт, что хронологически НМ 474 - самый ранний текст

${ }^{28}$ Ibidem, p. 87. Комментарий на приписке на л. 476-477об.: В ней писеи сообщает о себе и своей семье, что он происходит из Торопиа, что он десятый сын в семье (отчего и назван Матфей Десятый), что его родители и все братья и сестры удалились, каждый своим путем, в монастыри близ Полоцка, Вильны и Новгорода, и только он, Матфей, остался в миру на княжеской службе, но в конце жизни взамен монашеских подвигов решил написать книгу и оставить ее в том монастыре, где закончит свои дни. Этот сборник он начал писать в Вильне в 1502 г., а закончил в 1507 г. в Супрасльском монастыре (Ibidem, p. 55-56).

${ }^{29}$ И.И. Евсевв, Очерки по истории славянского перевода Библии, ХЧ 92.12, 1912, р. 1355. И потом добавляет: Любопытно, что составитель замючательнаго виленскаго библейскаго свода стоитъ въ самой тпсной связи съ Новгородомъ (Ibidem, p. 135).

${ }^{30} \mathrm{~J}$. Грковит-МЕјџор, op. cit.

${ }^{31}$ Д. Богданович опубликовал запись на Л. 426: G̈̈а книга ГАаГолєма Gилогизно изь олтајскє к8ћє

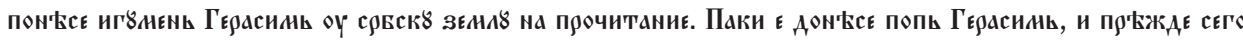

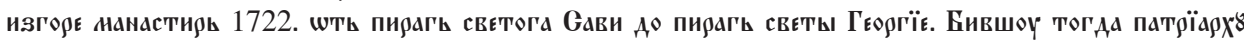

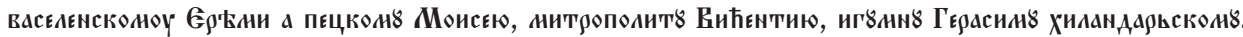

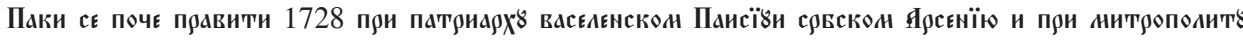

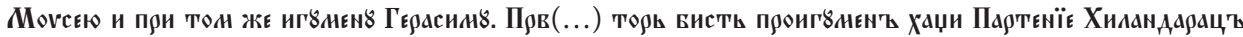

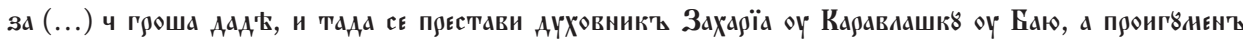

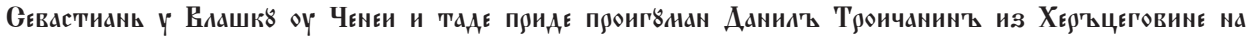
поклонємїв (Д. БОГДАНОвИЋ, Каталог ћирилских рукописа манастира Хиландара, vol. I, Београд 1978, p. 181).

32 Исследовательница приняла мнение Д. Драгойловича, что в православном мире распространялись два типа текста Апокалипсиса: старый, подобный НМ 474, и младший, с комментариями св. Андрея Кесарийского (по: D. DraGoJLović, Apokalipse bosanskih krstjana i staroslovensko književno nasleđe, КИ 13 (52), 1981, p. 605). 
этой редакции. Анализ полученных данных в этом смысле опроверг общепринятый тезис Й. Хама о западном глаголическом пути проникновения текста в Боснию ${ }^{33}$.

С другой стороны, важно, что НМ 474 связывается с толковой версией книги - не только по названию глав и стиха 17,3 (о нем смотри ниже), но и по трем интерполяциям из толкований св. Андрея Кесарийского. Они до сих пор не отмечены в исследованиях:

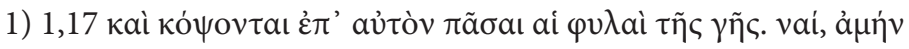

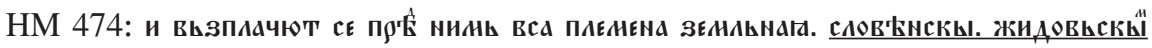

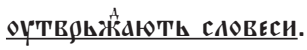

\section{Остальные редакции текста:}

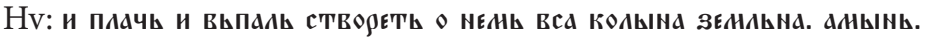

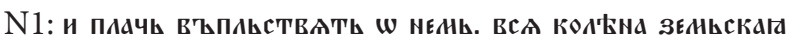

С̆: И ВСПАДЧюТ СА О NЁ ВСА ПАЕНЕНА ЗЕННАТ. ЕИ АНЙ

Pl 46: и вьсплач8ть ш нюдь вьси єзыци зенльсцїн. юи алинь

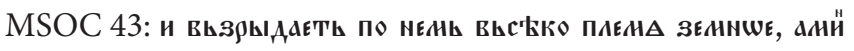

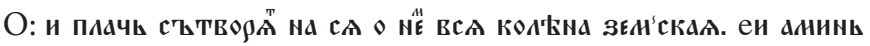

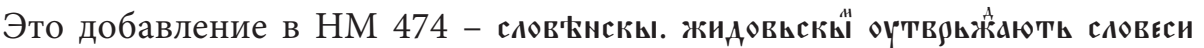
- не встречается в библейском тексте других версий книги, оно, как правило, имеется только в славянских толковых списках. В толковании к 1,7 в гре-

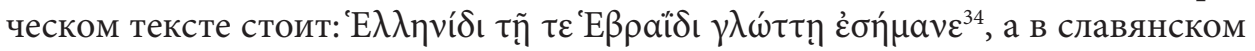

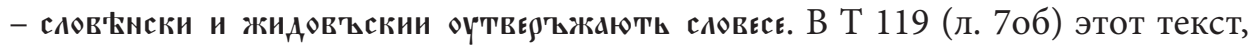
например, оформлен как заголовок киноварью (Фиг. 5).

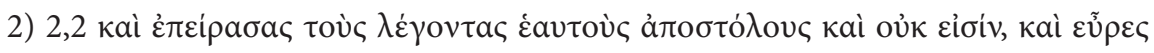
aủंoùৎ $\psi \varepsilon \mathcal{\varepsilon} \delta \varepsilon \tilde{\iota} \varsigma$.

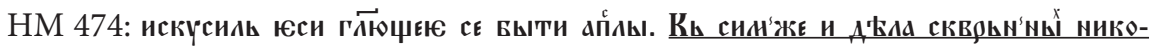

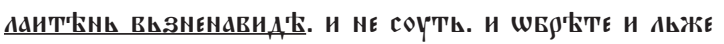

\section{Остальные редакции текста:}

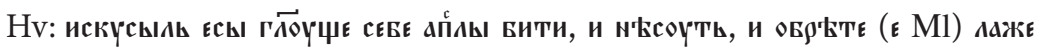

${ }^{33}$ J. НАмм, op. cit., p. 52-63; Ј. ГРКОвит-МЕјџОР, op. cit., p. 317-318.

${ }^{34}$ J. Schmid, Studien zur Geschichte des griechischen Apokalypse - Textes, vol. I. Der Apokalypse

- Kommentar des Andreas von Kaisareia. Text, München 1955, p. 17. 


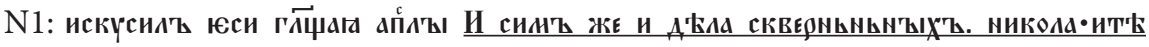

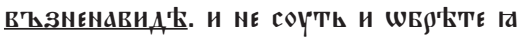

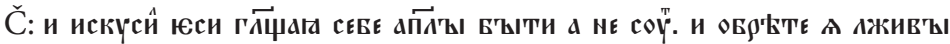

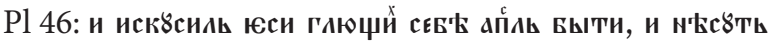

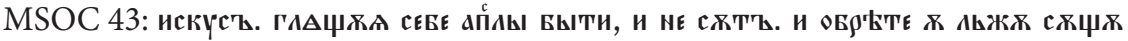

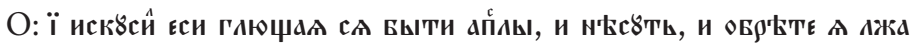

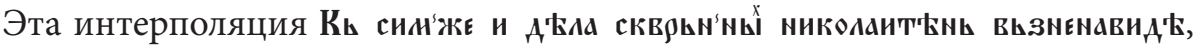
которая помещена внутри библейского стиха, тоже взята из толкований. Она нетипична для боснийских текстов, как и для остальных нетолковых списков. Но она встречается в некоторых восточнославянских комментированных списках, где тоже находится на этом месте в середине библейского стиха (срв. N1).

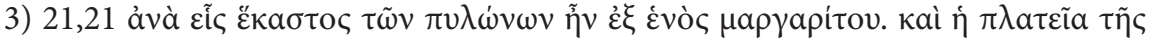

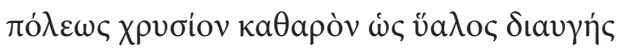

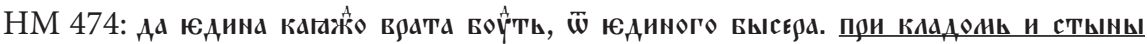
вышнаго геӑ

Остальные редакции текста:

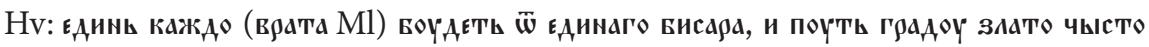
ТКО стакАо чисто (- Ml) АастеЕ се

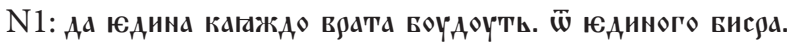

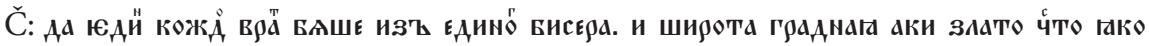
стькАо озА९Аючи

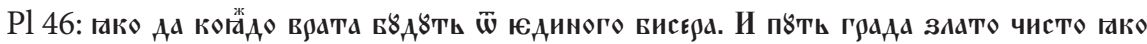
сTLKAO СLBTE $\mathfrak{C E}$.

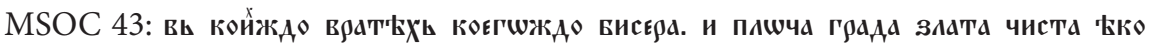
и свњт"ъ.

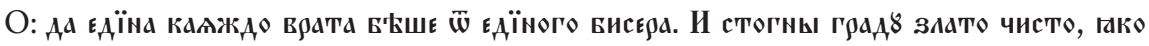

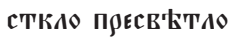

Эта интерполяция в основном тексте НМ 474 - при клддоны и стыны вышнаго гяА̊, находится только в этой рукописи, она часть толковой версии книги. Поскольку стих 21,21 - один в латинской традиции, а в книге св. Андрея Кесарийского ему соответствуют 2 стиха с двумя толкованиями, для большей ясности приводится цитата по ранней редакции текста с толкованиями (N1 с разночтениями по T119), представитель правленного текста толковой версии F15 XVI в. и греческий текст: 
N1 (разночтения по Т119)

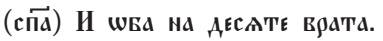

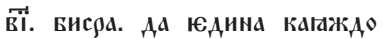

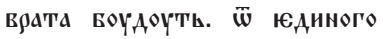

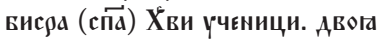

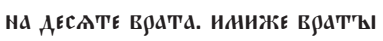

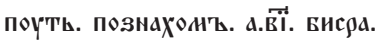
шї ґ́ юдиного висла. инуоџа лџанию (сп̈в) При кАадонь истинҚ. въышьнато ГЛада. БАГ'ҚҚ'Қ НЕ НОЖЕТЬ С'ҚСТАВИТИ. НАА'Қ ВСен БО ЮстТ (-) слоуХОА'ъ. и виденниєаь. (и)

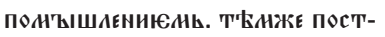
Ааниєе градоу. гако заӟ нногы

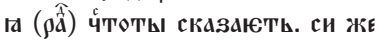

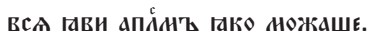

$\underline{\text { F15 }}$

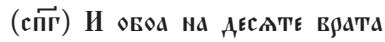

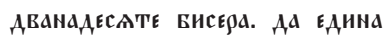

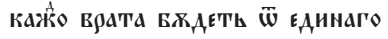
Бисера. (тய̈) Хви ҮЧЕници,

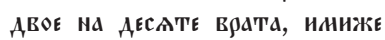

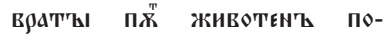

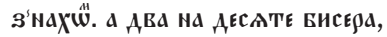
ИАУЧИ БАЕџаNїЕ. (сก̈) ПХТЬ Бо граде sАато чисто. тако

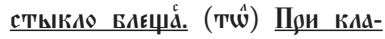

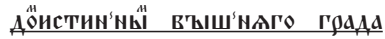

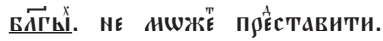
Паче БО ВеАКОГО слоуХа

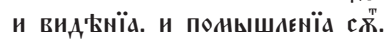

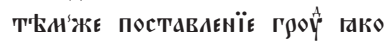
SAdTo наногї чистоты $\rho a^{\text {Ä̈ }}$

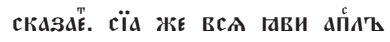
гкК К ножАаше.

\section{J. Schmid, Studien zur...}

$$
\text { p. } 248
$$

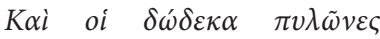

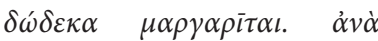

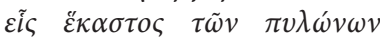

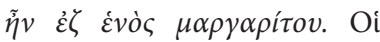
$\delta \omega ́ \delta \varepsilon \kappa a \quad \pi v \lambda \tilde{\omega} v \varepsilon \varsigma, \quad \delta \eta \lambda a \delta \dot{\eta}$

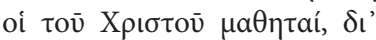

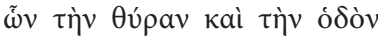

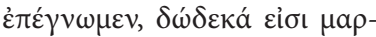

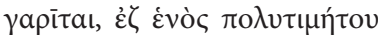

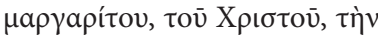

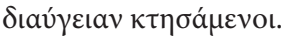

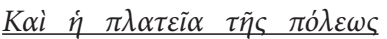

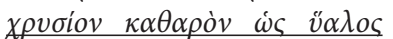

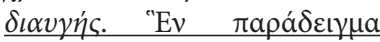

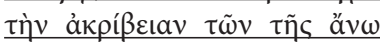

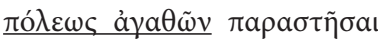

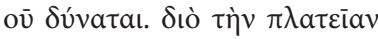

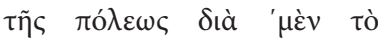

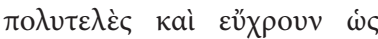

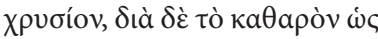

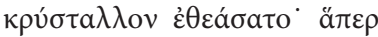

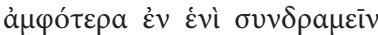

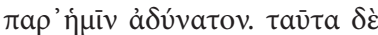

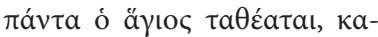

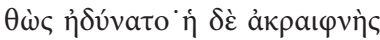

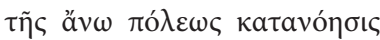

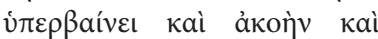

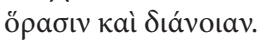

Эта путаница в библейском тексте - лакуна второй части библейского стиха в ранних списках N1 и Т119, наводит на мысль, что НM 474 хоть и связана с боснийскими текстами, но в большой степени - также и с ранней традицией текста с комментариями.

Я. Гркович-Мейджор связывает появление этой рукописи с расцветом исихазма на Афоне в XIV в ${ }^{35}$. В тексте на фонологическом и морфологическом уровне прослеживается высоко стандартизированная сербская редакция старославянского языка, а в отличие от боснийских списков, находятся

\footnotetext{
${ }_{35}^{35 а н и м љ и в о ~ ј е ~ д а ~ с у ~ и с и х а с т и ~ б и л и ~ о п т у ж и в а н и ~ з а ~ ј е р е т и ч к у ~ м е с а л и ј а н с к у ~ о р и ј е н т а и и ј у, ~}$ као што је Црква босанска, у оквиру које су три босанске апокалипсе настале, без утеметьних доказа оптуживана као богумилска (Ј. Грковит-Мејџор, ор. сіt., р. 313).
} 
и некоторые лексические варианты, типичные для т.н. преславской школы

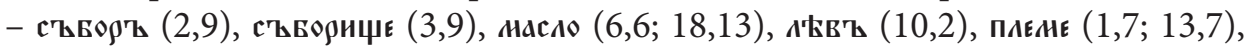
влддымица $(17,5)$. Она отмечает, что между этими копиями текста нет противопоставления в использовании „охридской” и/или „преславской” лексики. И ставит вопрос: лежат ли в основе НМ 474 и боснийской редакции Откровения различные переводы, или НМ 474 является результатом поздней, вероятно, святогорской исихастской редакции Апокалипсиса, чей первоисточник находится и в основе боснийских текстов.

\section{Хорватские глаголические фрагменты}

Эта редакция текста Апокалипсиса находится в хорватских богослужебных книгах (бревиариях и миссалах). Эти рукописи известны с конца XIII - начала XIV в. и до XVI в. В них текст сегментирован на 22 главы, согласно латинской традиции, но перевод сделан с греческого языка (Фиг. 6).

Их изучение началось в 1886 г., когда И. Берчич опубликовал эти фрагменты $^{36}$. В 2002 г. Я. Юрич-Капел потвердила, что боснийские списки имеют общий источник, который лежит и в основе хорватского списка Vid (1396 г.), и в основе сербской копии текста HM 474, как и в Rum - представителе восточнославянской толковой традиции ${ }^{37}$. Она обратила внимание на интерполяцию из толковой редакции книги в 17,3, которая является общей для боснийских текстов, Vid и HM 474:

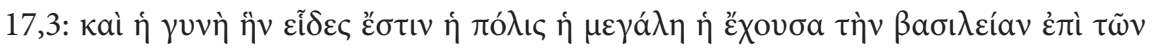
$\beta a \sigma \iota \lambda \varepsilon \dot{\varepsilon} \omega \nu \tau \tilde{\eta} \varsigma \gamma \tilde{\eta} \varsigma$

Vid: žena juže vide gradb veliki est'. iže imat' c(êsa)r(st)vie nad'c(êsa)ri z(e)ml'nimi

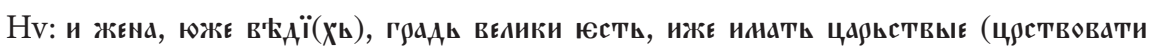
Ml) нады цары зендьниян.

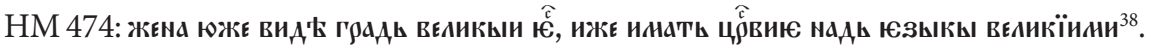

Этот пример становится весьма интересным, поскольку эта интерполяция - часть толкования на 17,3 (где цитируется 17,18) - стоит и в других ранних толковых списках как Т119 и Rum (Фиг. 7), где она встречается в основном тексте и имеет свое толкование, но не присутствует, например, в N1, как и в поздних нетолковых списках редакции С̆ $\check{C}^{39}$.

${ }^{36}$ I. BERČIĆ, op. cit.

${ }^{37}$ J. JURIĆ-KAPPEL, op. cit.

${ }^{38}$ Ibidem, p. 77.

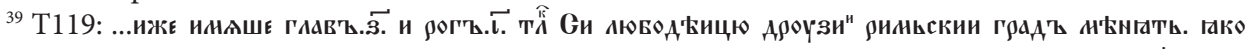

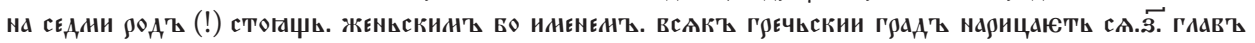


Результаты исследования Я. Юрич-Капел подтверждают выводы, которые сделал еще В. Облак: предположение о южном пути движения текста Апокалипсиса, как представляется, из Афона через Македонию, Боснию и на северо-запад, в Хорватию. Подтверждением этому служит и отсутствие т.н. „паннонизмов” или „моравизмов” в хорватских глаголических списках книги. Исследовательница приводит и некоторые примеры употребления

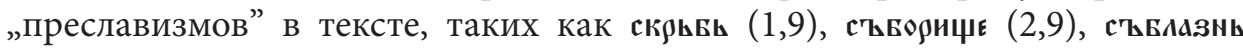
$(2,14)$, съьоръ $(3,9)$, влддница $(17,5)$. Нерешенным, разумеется, остается вопрос, из какого первоисточника появились в Vid и HM 474 эти преславизмы, которых нет в боснийских списках. М. Михалевич также отмечает важное значение Vid для гипотезы о јužnom putu dolaska staroslavenskoga bogoslužja i jezika u hrvatske krajeve - взаимодействие, которое могло бы объяснить связь с боснийскими рукописями ${ }^{40}$.

\section{Южнославянская толковая версия}

Недавно были опубликованы данные о неизвестной до сих пор в научной среде южнославянской толковой редакции Апокалипсиса с комментариями св. Андрея Кесарийского (Фиг. 8$)^{41}$. Эта редакция, в отличие от известных уже книг с комментариями, не имеет вводной части, нет делений на слова, стихи или главы, как это наблюдается у св. Андрея Кесарийского. Тут деление на главы следует латинской традиции: они введены порядковым номером (напр. глава .Аि.), библейский текст введен с с⿱8щює, а комментарии - с тыькь. Редакция библейского текста имеет свои специфические особенности, а толкования, которые являются своеобразной редакцией комментариев св. Андрея Кесарийского, значительно отличаются от уже знакомых.

Эта редакция известна только среди южных славян. Она является частью сборников, которые сохранены с XV и XVI вв. и известна в 3 списках: 1) Сборник из монастыря Плевля (Pl 46). В. Мошин предполагает, что это сборник первой четверти XV в. ${ }^{42}$, а Р. Станкович по водяным знакам датировал его концом XVI в. (1590-1600 г. $)^{43}$. Текст Апокалипсиса начинается с самого начала рукописи $($ от 1,5$)$ и сохранен до конца. Имеются лакуны между

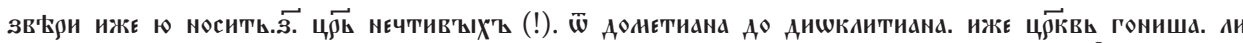

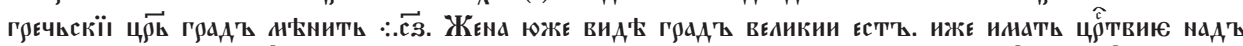

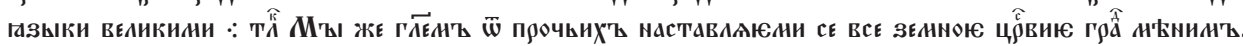

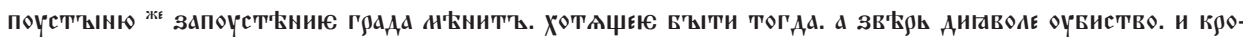

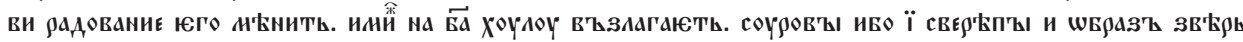
ЖЕ И Черваєната "

${ }^{40}$ M. Minaljević, Jezična slojevitost Brevijara Vida Omišljanina iz 1396. godine, Filol 29, 1997, p. 136.

${ }^{41}$ И. ТрифоновА, Южнославянската редакция на Тълковния...

${ }^{42}$ В. Мошин, Ћирилски рукописи манастира св. Тројице код Плеваль, ИЗ.ЕН 14, 1958, р. 242.

${ }^{43}$ Р. Станковић, Рукописне књиге манастира Свете Тројище код Пъеваља. Водени знаци и датирағе, Београд 2003, p. 16-17. 
л. 606 и л. 7 (от 2,3 до части стиха 2,7). 2) Сборник из Печской патриархии (Р 99). Эта рукопись сегодня в очень плохом состоянии. В. Мошин считает, что она написана в последней четверти XVI в., а М. Грозданович и Р. Станкович предположили, что она датируется началом XVII в. (1610-1615) ${ }^{44}$. Текст Апокалипсиса помещен от л. 1 до л. 92, начинается с конца 4,5 и сохранен до конца. 3) Апокалипсис толковый, XVI в. (MSOC 101). Он сохранен частично, только 22 л. Текст начинается в начале 13 главы и кончается в начале 17 главы. Есть лакуны между л. 1 и л. 2 (часть комментария 13,4 до библейского текста 13,10 включительно), как и между л. 5 и л. 6 (от комментария к 14,1 до части библейского стиха 14,5).

Эти списки показывают общую тенденцию, типичную для поздних редакций Апокалипсиса (как С̆, Pl 46, O, F, MSOC 43): они не так гомогенны в лексическом отношении, и в них можно найти много примеров самостоятельных переводческих решений и контекстуально обусловленных замен слов. Это показывает своеобразное переосмысление текста, которое приводит к лексическим различиям, как результат деятельности в различное время и в различных местах преславских книжников, и предпринятых компромиссов в афонской редакции.

Все три сборника имеют одинаковый состав, сербские орфографические особенности - одноеровые, безюсовые, без украшений. B Pl 46 и P 99 текст идентичен, несмотря на то, что имеются некоторые морфологические отличия, несущественные различия в порядке слов или отдельные лексические замены, у них, без сомнения, общий источник. MSOC 101 восходит к тому же источнику, но не непосредственно - он содержит и дополнительное редактирование. Текстовая версия, которая стоит в основе этих списков, наверное, содержит тот же самый первоначальный славянский перевод Откровения. В этой редакции толкования являются неделимой частью библейского текста. И толкования, и библейский текст подвергались вторичной редакции, и это, вероятно, относится к деятельности афонских монастырей в XIV в. Слово Епифания Кипрского о двенадцати камнях, которое помещено в составе Апокалипсиса при описании Небесного Иерусалима (21 глава), занимает логическое место в контексте и содержании книги, и его присутствие здесь можно считать особенностью первоисточника. Этот первоисточник был, наверное, частью сборника, предназначенного для чтения в монашеском центре. А сам сборник был составлен, вероятно, в южнославянских землях или южнославянскими монахами в середине или в конце XIV в. К этому выводу приводят и содержащиеся в его составе Слово Епифания Кипрского и Сказание Афродитиана ${ }^{45}$.

\footnotetext{
${ }^{44}$ М. ГрОзДАновић-Пајић, Р. СтАнковић, Датиране и водени знаци сриских ћирилских рукописних къига Пећке патријаршије, АПри 13, 1991, р. 54-55.

${ }^{45}$ И. ТрифоновА, Южнославянската редакиия на Тълковния..., p. 125.
} 


\section{Болгарская календарная версия Апокалипсиса без толкований}

В этом сложном контексте важное место занимает еще одна отдельная редакция Откровения св. Иоанна Богослова. О ней до сих пор очень мало известно, обычно ученые определяют ее как македонскую, как это сделано в описании Д. Богдановича (на базе MSOC 43$)^{46}$, несмотря на статью К. Ивановой, опубликованную в 1972 г., где исследовательница определила ее как болгарскую ${ }^{47}$.

Эта редакция - нетолковая, в ней нет никаких следов толковой версии книги св. Андрея Кесарийского. Она входит в состав новоизводных календарных сборников под датой 8 мая (день памяти св. Иоанна Богослова), а хронологически эти сборники датируются с середины XIV по XVII в. В них отражена восточноболгарская тырновская литературная традиция передачи текста (Фиг. 9) ${ }^{48}$.

До настоящего времени известны пять списков этой версии книги, в последний раз они описаны в каталоге К. Ивановой $\left.{ }^{49}: 1\right)$ Календарный сборник избранных житий на январь-июль с нарушением календарного порядка, cер. XIV в. (ок. 1350), л. 61-79об. Писан полууставом, орфография - с двумя ерами, тремя юсами, болгарская, текст без украшений или миниатюр. Он хранится в Музее Сербской Православной Церкви под № 43, куда поступил из Крушедольского монастыря (MSOC 43) ${ }^{50}$. 2) Календарный сборник на декабрь-июль, сер. XV в. (1441 г.), л. 171-189об. Писан полууставом, орфография болгарская - двуеровая, двуюсовая. Он написан Гавриилом Уриком. Рукопись принадлежала монастырю Нямц. В настоящее время она хранится в библиотеке Румынской академии наук в Бухаресте, под сигнатурой Sl. 165 (R 165)51. 3) Календарный сборник на апрель-июнь, XVII в.,

${ }^{46}$ Д. БогдАновић, Инвентар ћирилских рукописа у Југоставији (XI-XVII века), Београд 1982, p. 32.

${ }^{47}$ К. ИвановА, Археограбски бележки от книгохранилищата в Югославия, ЕЛ 27.4, 1972, p. 52-55.

${ }^{48}$ И. Трифонова, Лексиката на най-стария български препис на Апокалипсиса на св. Йоан Богослов в контекста на българските преводачески школи през Средновековието, София 2008 .

${ }^{49}$ К. Иванова, Bibliotheca hagiographica balcano-slavica, София 2008, p. 529 (за исключением списков Хил445 и Хил474, которые являются представителями другой редакции текста); K. Ivanova, Canonic and Apocryphal Texts from the Bible in Balkan Calendrical Miscellanies (Based on Material from Bibliotheca Hagiographica Balcano-Slavica), [in:] The Bible in Slavic Tradition, ed. A. Kulik, C.M. MacRobert, S. Nikolova, M. Taube, C.M. Vakareliyska, Leiden-Boston 2016, p. 494-495 (= SJsl 9).

${ }_{50}$ Д. БогдАновић, Инвентар ћирилских рукописа..., p. 32; V. Mošın, Izvještaj o naučnom putovaniju u Srjemsku Mitrovicu, Beograd, Peć, Dečane, Cavnat, Dubrovnik 1953. godine, [in:] Inventar ćirilskih rukopisa Muzeja Srpske pravoslavne crkve u Beogradu, LHAZU 60, 1955, p. 218-226; С. Петковић, Опис рукописа манастира Крушедола, Сремски Карловци 1914, p. 212-213.

${ }^{51}$ P. Panaitescu, Manuscrisele slave din Biblioteca Academici RPR, vol. I, Bucureşti 1959, p. 248-250. Я хочу поблагодарить Анисаву Милтенову за возможность работать с текстом рукописи. 
л. 57-69, писан полууставом, молдавский по происхождению. Орфография - двуеровая и двуюсовая, тырновская. Рукопись принадлежала монастырю Молдовица, затем была в монастыре Драгомирна в Буковине, где находится и теперь под шифром 1828/73952. 4) Календарный сборник на февраль-май, XVII в., л. 144-159об, без начала и конца, с недостатком, писан полууставом, молдавский. Орфография тырновская, но в отдельных текстах встречаются и русизмы. Эта рукопись была подарена монастырю Драгомирна от сучавского митрополита Анастасия Кримки. Теперь она находится во Львовской научной библиотеке им. В. Стефаника Национальной академии наук Украины, в коллекции Петрушевича № $2^{53}$. 5) Календарный сборник на апрель-май, написан в 1474 г., находится в коллекции монастыря Путна № 31, л. 59-81o654. Издание этой версии Откровения предстоит в будущем.

В заключение можно сказать, что, несмотря на разнообразие вариантов текста, сравнение показывает, что в основе всех указанных списков Апокалипсиса лежит общий первоначальный славянский перевод, отредактированный в разное время и в разных местах. Этот перевод обнаруживается одновременно и в восточнославянских толковых книгах, и в боснийских нетолковых кириллических списках, и в части хорватских глаголических фрагментов, и в сербском списке текста. Позже он был отредактирован в трех разных вариантах - в составе библейских сводов в русских и болгарских списках (С̌, Tl, U310, T710), в болгарских календарных новоизводных сборниках, в сербских списках с толкованиями св. Андрея Кесарийского.

Существуют две возможности возникновения самой ранней версии текста книги: либо это перевод св. Мефодия, к которому в Болгарии были добавлены толкования, либо перевод св. Мефодия был потерян и перевод был выполнен снова в Болгарии вместе с комментариями св. Андрея Кесарийского. Мне кажется, что более вероятна вторая возможность, но надо отметить, что в тексте нет большого количества преславизмов, как следовало бы ожидать для перевода, сделанного в Болгарии, и как было в других библейских книгах с толкованиями, составленных в Преславе (Книга пророков Исайи, Даниила, Книги Двенадцати Пророков). После этого перевод появился на Руси, где распространение Апокалипсиса с толкованиями приобрело большую популярность. В это время в среде южных славян библейский текст вторично был выделен из толковой книги. Это могло

\footnotetext{
52 3. Юфу, За десеттомната колекиия Студион (Из архива на румбнския изследвач Йон Юфу), SB 2, 1970, p. 326-329; Е. КАлужняцки, Werke des Patriarches von Bulgarien Euthimius (1375-1395), Wien 1901, p. cvl.

${ }^{53}$ I. Свєнцїцький, Опис рукописів Народного Дому з колєкиії Ант. Петрушевича, vol. I. Українсько-руський архів, Львів 1906, p. 108-112.

${ }^{54}$ P. Popescu, Manuscrise slavone din manistirea Putna, ВОR 1-2, 1962, p. 105-145; И. Тодоров, Из рбкописната сбирка на манастира Путна, СЛ 10, 1981, p. 76-78.
} 
быть сделано в Болгарии или Сербии, а, возможно, и в Боснии. Книга дошла до Боснии, вероятно, через богомилов, и там был распространен библейский текст, отделенный от интерпретаций. Потом текст был отредактирован дополнительно в Болгарии для больших календарных тырновских сборников, и, вероятно, на Афоне, в его толковой и нетолковой версии, при составлении библейских корпусов и для монастырского чтения.

\section{Библиография}

\section{Источники}

С̆: Апокалипсис Чудовского Нового Завета, без толкований, русский, 1355 г., л. 148об-16655.

F15: Апокалипсис толковый, русский, с болгарскими орфографическими особенностями, XVI в., л. $122-283^{56}$.

HM 474: Апокалипсис, без толкований, сербский, последняя четверть XIV в., 365-379oб, Хилендарский монастырь, № $474^{57}$.

Hv: Апокалипсис Хвалового сборника, без толкований, боснийский, 1404 г., л. 133-151, Болонская Университетская библиотека, шифр $3575 \mathrm{~B}^{58}$.

Ml: Апокалипсис, без толкований, боснийский, XV в., л. 128-143 (без начала - от 1,6), Венеция, Библиотека Марчиан, Cod.slav.I-22759.

MSOC 43: Апокалипсис, без толкований, болгарский, XIV в., л. 61-79об, Белград, Музей Сербской Православной Церкви, № $43^{60}$.

N1: Апокалипсис толковый, пергамен, XIII в., 108 л., Санкт-Петербург, БАН, собр. Никольского, № $1^{61}$.

NB101: Апокалипсис толковый, сербский, XVI в., 22 л., София, Национальная библиотека, № $101^{62}$.

P99: Апокалипсис толковый, сербский, последняя четверть XVI в., Белградская народная библиотека, собр. Печской патриаршии, № $99^{63}$.

${ }^{55}$ W. Lehfeld, Neues Testament des Čudov-Klosters, Köln 1989 (= BGLS).

${ }^{56}$ M. MAtejIC, Slavic Manuscripts from the Fekula Collection: A Description, Columbus 1983, p. 79-81;

P. Matejic, H. Thomas, Catalog Manuscripts on Microform of the Hilandar Research Library (The Ohio State University), vol. I, Columbus 1992, p. 88.

${ }^{57}$ Д. БогдАновић, Каталог ћирилских рукописа..., p. 181; Р. МатејІ, Н. Тномаs, Catalog Maпuscripts..., p. 562.

${ }^{58}$ Текст издан два раза - впервые Д. Даничичем: Đ. DANIČıć, Hvalov rukopis...; IDEM, Apokalypsa iz Hvalova rukopisa..., а потом еще раз под редакцией Х. Куны: Н. KunA, op. cit.

${ }^{59}$ M. CAPALDo, Les manuscrits slaves et leur etude en Italie, ПК 1, 1978, p. 15-33; H. KunA, op. cit.

${ }^{60}$ Ibidem, p. 32; V. Mošsn, op. cit.; С. Петковић, op. cit., p. 212-213.

${ }^{61}$ Сводный каталог славяно-русских рукописных книг, хранящихся в СССР, XI-XIII в., еd. О. Шмидт, Л.П. ЖуковСКАЯ, Н.Н. ПокРОвСКИЙ et all., Москва 1984, p. 241; Е.Ф. КАРСКИЙ, Славянская кирилловская палеография, Ленинград 1928, р. 378-279.

${ }^{62}$ Б. Цонев, Опис на рвкописите и старопечатните книги на Народната библиотека в София, vol. I, София 1910, p. 78.

${ }_{63}^{6 .}$ Д. БогдАновић, Инвентар ћирилских рукописа..., p. 120. 
Pl: Апокалипсис толковый, сербский, первая четверть XV в., л. 1об-122об, Белградская народная библиотека, собр. Плевли, № $46^{64}$.

R165: Апокалипсис, без толкований, болгарский, XV в., л. 171-189oб, Бухарест, PAH, Sl.16565.

Rad: Апокалипсис, без толкований, боснийский, сер. XV в., л. 1-56, Рим, Ватиканская апостольская библиотека, Cod.illir.126.

Rum: Апокалипсис толковый, русский, пергамен, нач. XIV в., Москва, РГБ, фонд 256, собр. Румянцева, № $8^{67}$.

SSMD: Апокалипсис, без толкований, молдавско-валашские орфографические особенности, 1507 г., л. 290-298об., Санкт-Петербург, БАН, фонд 27, 24.4.2868.

T119: Апокалипсис толковый, русский, XIV в., л. 1об-152об., Москва, РГБ, фонд 304, собр. Троице-Сергиевой лавры, № $119^{69}$.

T710: Апокалипсис, без толкований, русский, с болгарскими орфографическими особенностями, 1493 г., л. 156-166, Москва, РГБ, фонд 304, собр. Троице-Сергиевой лавры, № 710.

Tl: Апокалипсис, толкования после библейского текста книги, русский, XV в., 1об-39 (л. 396-125 толкования), Санкт-Петербург, РНБ, фонд 7, собр. Толстого, Q.п.I.6.

U310: Апокалипсис, без толкований, русский, XV в., л. 431-442, Москва, РГБ, фонд 310, собр. Ундольского, № 1.

Vid: Апокалипсис Вида Омишлянина, без толкований, хорватский, 1396 г., Вена, Австрийская национальная библиотека, Cod.slav.3.

\section{Литература}

Алексеев А.А., Текстология славянской библии, Санкт-Петербург 1999.

АЛЕКСеЕв А.А., О.П. ЛИХАЧЕвА, К текстологической истории древнеставянского апокалипсиса, [in:] Материаль и сообщения по фондам Отдела рукописной и редкой книги БАН СССР 1985, ed. А.И. КоПАнев, Ленинград 1987, p. 8-22.

АЛЕксеЕв А.А., О.П. ЛиХАчевА, Супрасльский сборник 1507 г., [in:] Материалы и сообщения по фондам Отдела рукописной и редкой книги БАН СССР, ed. М.В. КукушкинА, Ленинград 1978, p. 54-88.

Ануфриева Н.В., И.В. Починская, Лицевые Апокалипсисы Урала: Православная традиция и элементы европейского культурного влияния, Екатеринбург 2014, p. 4-21.

Арсеній, Описаніе славянскихъ рукописей библіотеки Свято-Троицкой Сергіевой лавры, vol. I, Москва 1878.

БАвин С.П., Г.В. Попов, Откровение св. Иоанна Богослова в мировой книжной традици: Выставка, Москва 1995.

\footnotetext{
${ }^{64}$ Ibidem.

${ }^{65}$ P. PANAItescu, op. cit., p. 248-250. Я хочу поблагодарить Анисаву Милтенову за возможность работать с этой рукописью и с текстом SSMD.

${ }^{66}$ F. RAс̌кI, op. cit.; А. Джурова, К. СтАнчев, М. ЯПунджич, Опис на славянските ръкописи във Ватиканската библиотека, София 1985, р. 164-165.

${ }^{67}$ Текст издан архимандритом Амфилохием (Новый завптг господа нашего...).

${ }_{68}^{6 . А . ~ А Л Е К С е Е в, ~ О . П . ~ Л И Х А ч е в А, ~ С У п р а с л ь с к и и ̆ ~ с б о р н и к . . ., ~ р . ~ 55-56 . ~}$

${ }^{69}$ Арсеній, Описаніе славянскихъ рукописей библіотеки Свято-Троицкой Сергіевой лавры, vol. I, Москва 1878, p. 87-88.
} 
БогдАновит Д., Инвентар ћирилских рукописа у Југославији (XI-XVII века), Београд 1982.

БогдАновит Д., Каталог ћирилских рукописа манастира Хиландара, vol. I, Београд 1978.

Буславв Ф.И., Русскій тицевой апокалипсисъ. Свод изображений из тицевых апокалипсисов по рукописям с XVI-го века по XIX-ыцй, Москва 1884.

Горский А.В., К.И. Невоструев, Описаніе Славянскихъ рукописей Московской синодальной библіотеки, Москва 1855, р. 157-160 (= MLSDV 2, 1964).

Грковит-Мејџор Ј., Хиландарска апокалипса Јована Богослова (ХИЛ 474), ЈФ 56.1-2, 2000, p. 311-320.

ГРОЗДАНОвит-ПАјИт М., Р. СТАНкОвит, Датираюе и водени знаци српских ћирилских рукописних књига Пећке патријариије, АПри 13, 1991, р. 7-249.

Джурова А., К. Станчев, М. ЯПунджич, Опис на славянските ръкописи във Ватиканската библиотека, София 1985.

Евсеев И.И., Очерки по истории славянского перевода Библии, ХЧ 92.12, 1912, р. 1342-1374.

Иванова К., Bibliotheca hagiographica balcano-slavica, София 2008.

Иванова К., Археограбски бележки от книгохранилищата в Югославия, ЕЛ 27.4, 1972, p. 51-57.

Иоанна Богослова Откровение, [in:] Православная энциклопедия, ed. Патриарх Московский и всея Руси Кирилл, vol. XXIV, Москва 2010, p. 705-745.

КАлужняцки Е., Werke des Patriarches von Bulgarien Euthimius (1375-1395), Wien 1901.

КАрский Е.Ф., Славянская кирилловская палеография, Ленинград 1928.

Мошин В., Ћирилски рукописи манастира св. Тројище код Пљеваља, ИЗ.ЕН 14, 1958.

Новый завптъ господа нашето І. Христа, писанный рукою святителя Алексія митрополита всея Россіи, сфотографированный въ 8-мь дней въ началь августу 1887 г. фотографомъ Александромъ Андреевымъ Багнеровскимг подъ непосредственнымъ наблюденіемъ Данитовскаго Архимандрита Амфилохія.

Оволенский М., Летописеи Переславля Суздальского, ВИМОИ 9, 1851, p. LIX-LXII.

Пентковская Т.В., Чудовская редакиия Нового завета и ее взаимоотномение с другими редакизиями, Pbg 27.3, 2003, p. 18-46.

Петковић С., Опис рукописа манастира Крушедола, Сремски Карловци 1914.

Попов Г.В., Апокалипсис в исскустве христианского мира, [in:] С.П. БАвин, Г.В. Попов, Откровение св. Иоанна Богослова в мировой книжной традици: Выставка, Москва 1995, p. 8-12.

Попов Г.В., Рукописи древнерусские в старообрядческой традиции, [in:] С.П. БАвин, Г.В. Попов, Откровение св. Иоанна Богостова в мировой книжной традиции: Выставка, Москва 1995.

Попов Г.В., Рукописи. Греческие и латинские, [in:] С.П. БАвин, Г.В. Попов, Откровение св. Иоанна Богослова в мировой книжной традиции: Выставка, Москва 1995, p. 13-28.

Свєнцїцький I., Опис рукописів Народного Дому з колєкції Ант. Петрушевича, vol. I. Українсько-руський архів, Львів 1906.

Сводный каталог славяно-русских рукописных книг, хранящихся в СССР: ХІ-ХІІІ вв., еd. О. Шмидт, Л.П. ЖуковскАЯ, Н.Н. ПокровскиЙ et all., Москва 1984.

Станковит Р., Рукописне књиге манастира Свете Тројице код Пљеваља. Водени знаци и датиране, Београд 2003.

Тодоров И., Из рбкописната сбирка на манастира Путна, СЛ 10, 1981, p. 71-87.

Трифонова И., Лексиката на най-стария български препис на Апокалипсиса на св. Йоан Богослов в контекста на българските преводачески школи през Средновековието, София 2008. 
Трифонова И., Южнославянската редакция на Твлковния апокалипсис (Речник-индекс и издание на запазената част от Националната библиотека „Св. Св. Кирил и Методий, Собия, № 101, XVI в.), Psl 22.1, 2014, p. 119-163.

Цонев Б., Опис на ръкописите и старопечатните книги на Народната библиотека в София, vol. I, София 1910.

Юфу 3., За десеттомната колекиия Студион (Из архива на румънския изследвач Йон Юфу), SB 2, 1970, p. 299-343.

BERČIĆ I., Ulomci svetoga pisma obojega uvjeta staroslavenskim jezikom. Skupio iz rukopisa i tiskanih knjiga hrvatskoga razreda, vol. V, Praga 1866, p. 108-145.

CAPALDO M., Les manuscrits slaves et leur etude en Italie, ПК 1, 1978, p. 15-33.

DANIČIĆ Đ., Apokalypsa iz Hvalova rukopisa, Star 4, 1872, p. 86-109.

DANIČIĆ Đ., Hvalov rukopis, Star 3, 1871, p. 1-146.

De Groote M., Oecumenii commentarius in Apokalypsin, Lovanii 1998 (= TEG 8).

Dragojlović D., Apokalipse bosanskih krstjana i staroslovensko književno nasleđe, КИ 13 (52), 1981, p. 603-610.

GrÜNBERG K., Die Apokalypse. Edition zweier Hyparchetypi, SSp 11, 1999.

GrÜNBERG K., Die kirchenslavische Überlieferung der Johannes-Apokalypse, HPS.LR 9, Frankfurt am Main-Berlin-Bern-New York-Paris-Wien 1996.

Grünberg K., Prolegomena zur Edition zweier Hyparchetypi der kirchenslavischen Johannes-Apokalypse, BESL 1, 1998, p. 97-106.

GrüNBeRg K., Zur lexikalischen Variation in der slavischen Überlieferung der Johannes-Apokalypse, [in:] Ars Philologica. Festschrift für Baldur Panzer zum 65. Geburtstag, ed. P. LANG, Frankfurt am Main-Berlin-Bern-Bruxelles-New York-Wien 1999, p. 639-648.

Намм J., Apokalipsa bosanskih krstjana, Slo 9-10, 1960, p. 43-104.

Hoskier H., The Complete Commentary of Oecumenius on the Apocalypse, Ann Abor 1928.

Ivanova K., Canonic and Apocryphal Texts from the Bible in Balkan Calendrical Miscellanies (Based on Material from Bibliotheca Hagiographica Balcano-Slavica), [in:] The Bible in Slavic Tradition, ed. A. Kulik, C.M. MacRobert, S. Nikolova, M. Taube, C.M. Vakareliyska, Leiden-Boston 2016, p. 494-495 (= SJsl 9).

JAGIĆ V., Analecta romana, ASP 25, 1903, p. 1-47.

Jurić-KAPPEL J., Bosanske apokalipse u svome (južno)slavenskom kontekstu, WSJ 48, 2002, p. 75-94.

Kuna H., Zbornik Hvala krstjanina, vol. I, Faksimile, vol. II, Transkripcija i komentar, Sarajevo 1986.

Latin Commentaries on Revelation (Ancient Christian Texts), ed. et trans. W. WeInRICH, Downers Grove 2011.

Lehfeld W., Neues Testament des Čudov-Klosters, Köln 1989 (= BGLS).

Matejic P., H. Thomas, Catalog Manuscripts on Microform of the Hilandar Research Library (The Ohio State University), vol. I, Columbus 1992.

Matejic M., Slavic Manuscripts from the Fekula Collection: A Description, Columbus 1983.

Minaljević M., Jezična slojevitost Brevijara Vida Omišljanina iz 1396. godine, Filol 29, 1997, p. 119-138. 
Mošın V., Izvještaj o naučnom putovaniju u Srjemsku Mitrovicu, Beograd, Peć, Dečane, Cavnat, Dubrovnik 1953. godine, [in:] Inventar ćirilskih rukopisa Muzeja Srpske pravoslavne crkve u Beogradu, LHAZU 60, 1955, p. 218-226.

Овцак V., Die kirchenslavische Übersetzung der Apokalypse, ASP 13, 1891, p. 321-361.

Panaitescu P., Manuscrisele slave din Biblioteca Academici RPR, vol. I, Bucureşti 1959.

Popescu P., Manuscrise slavone din manistirea Putna, BOR 1-2, 1962, p. 105-145.

RAČKI F., Dva nova priloga za poviest bosanskih patarena, Star 4, 1882, p. 21-29.

Schmid J., Der Apokalypsetext des Arethas von Kaisareia und einiger anderer jüngerer Gruppen, Athen 1936.

Schmid J., Studien zur Geschichte des griechischen Apokalypse - Textes, vol. I. Der Apokalypse - Kommentar des Andreas von Kaisareia. Text, München 1955.

ŠIDAK J., Marginalija uz jedan rukopis "crkve bosanske" u Mletačkoj marciani, Slo 6-8, 1957, p. 134-153.

\begin{abstract}
The Revelation of St. John the Theologian among Orthodox Slavs and in South-Slavonic Literature. The article focuses on the history of the Book of Revelation of St. John the Theologian among Orthodox Slavs in the Middle Ages. The aim is to present its place among the other biblical books, related to Cyril and Methodius' literary tradition and follow its origin, its way of life and spreading in the Slavia Orthodoxa. The two main versions of the distribution of the book are presented - without interpretations and with the interpretations of St. Andrew of Caesarea, while the specifics of the basic versions of the book are also presented (East Slavonic and South Slavic versions with commentaries, Bosnian Cyrillic version, the earliest Serbian transcript, Croatian Glagolitic fragments, Bulgarian calendar version). An opinion has been expressed that a common initial translation is at the root of all these versions of the book, which was accompanied by interpretations, and probably made in Bulgaria at the end of $9^{\text {th }}-10^{\text {th }} \mathrm{C}$. Subsequently, it has been edited at different times and in different locations, placed in the composition of different collections, or as a separate book.
\end{abstract}

Ключевые слова: Откровение св. Иоанна Богослова, Апокалипсис, история текста среди восточных славян в Средние века, редакции текста, южнославянские списки.

Keywords: Apocalypse St. John the Theologian, the history of the text in the Middle Ages, the version of the text, South Slavonic copies.

Iva Trifonova

Cyrillo-Methodian Research Centre

13 Moskovska Str.

1000 Sofia, Bulgaria iva_3@abv.bg 


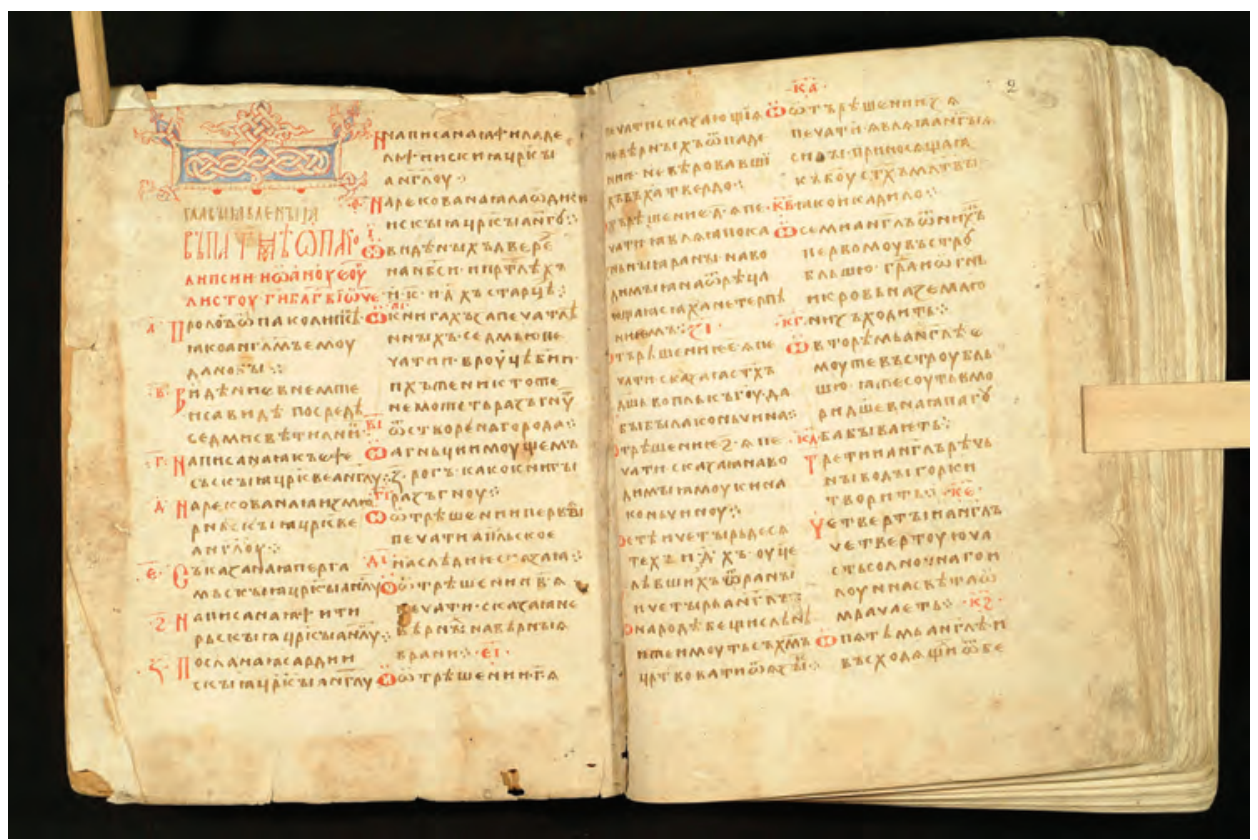

Фиг. 1. T119: Апокалипсис толковый, русский, XIV в., л. 1об-2.

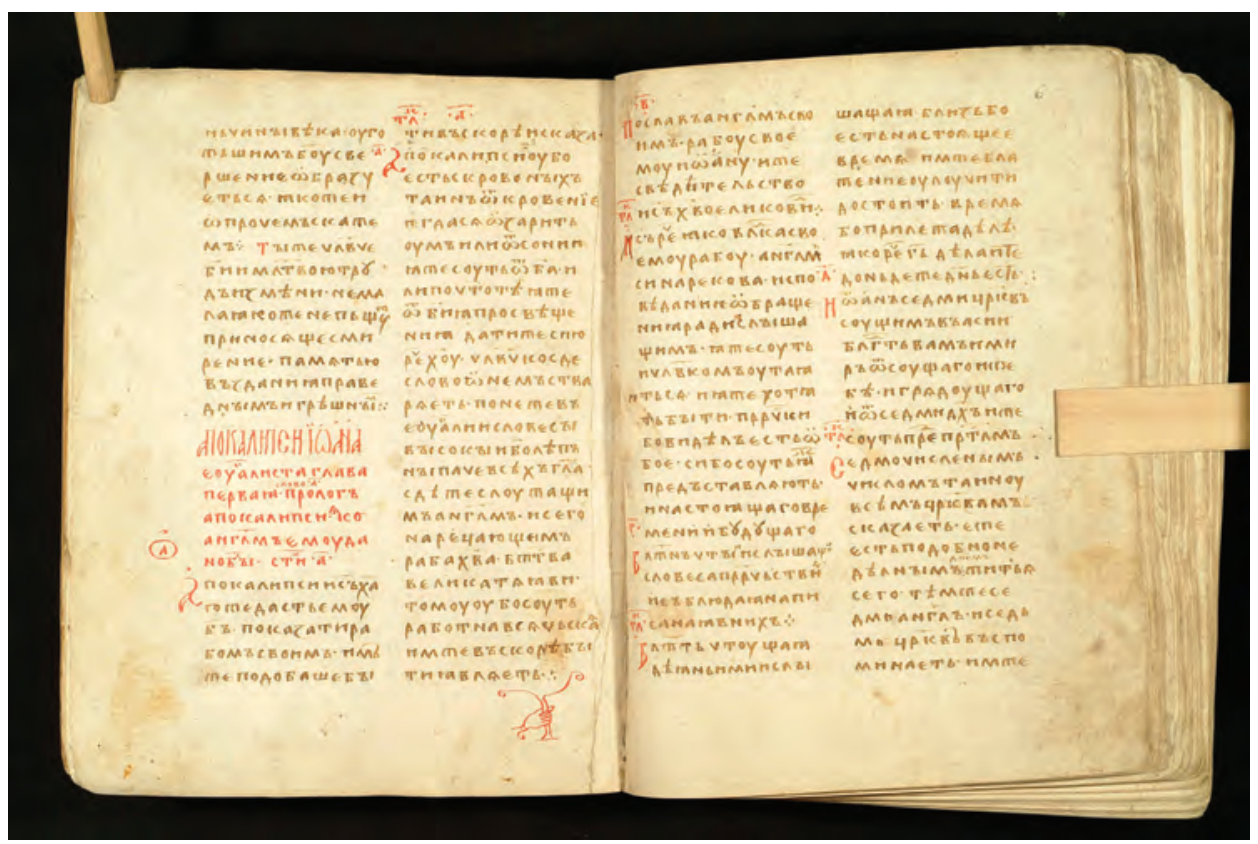

Фиг. 2. Т119: Апокалипсис толковый, русский, XIV в., л. 5о6-6. 


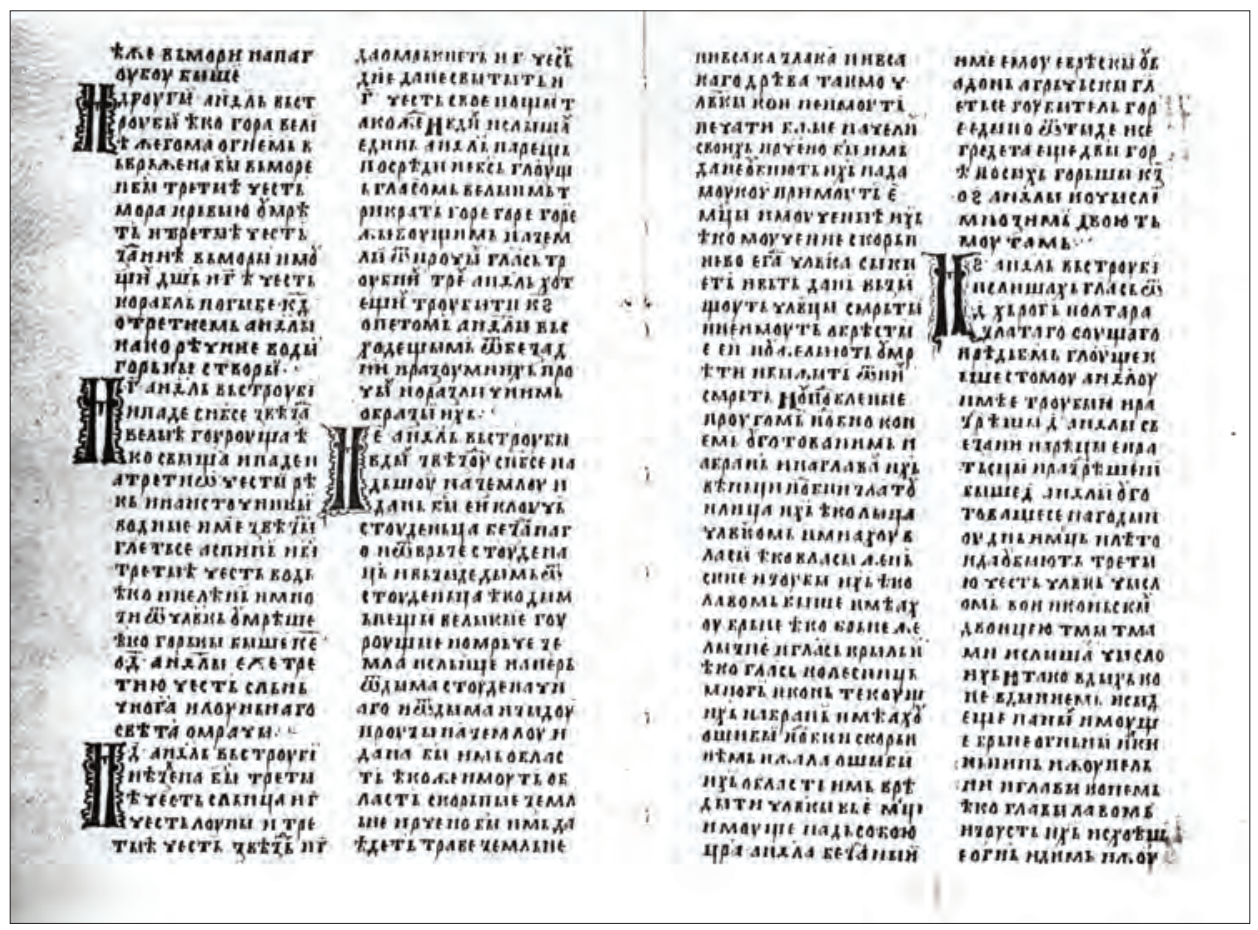

Фиг. 3. Нv: Апокалипсис Хвалового сборника, без толкований, боснийский, 1404 г., л. 140.

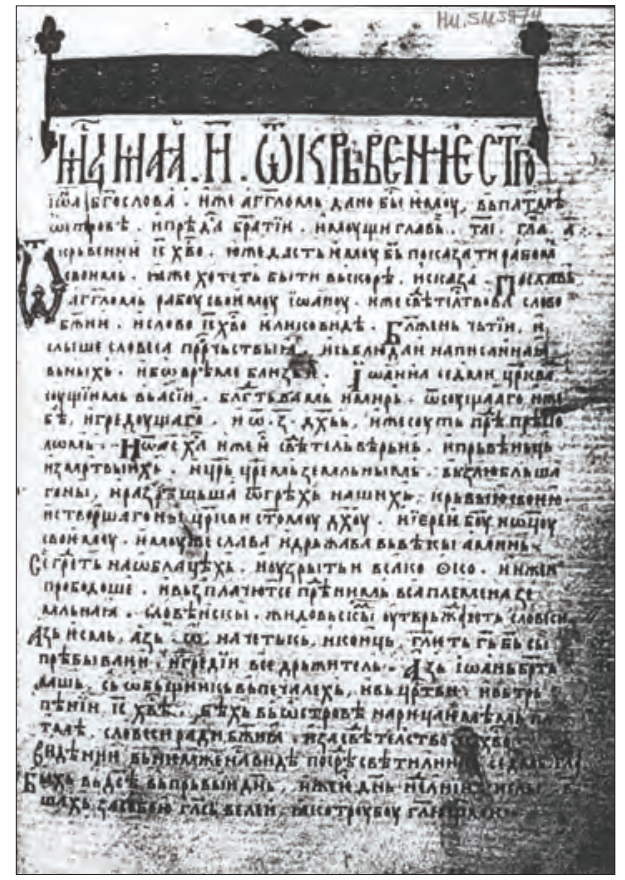

сербский, последняя четверть XIV в., л. 365. 


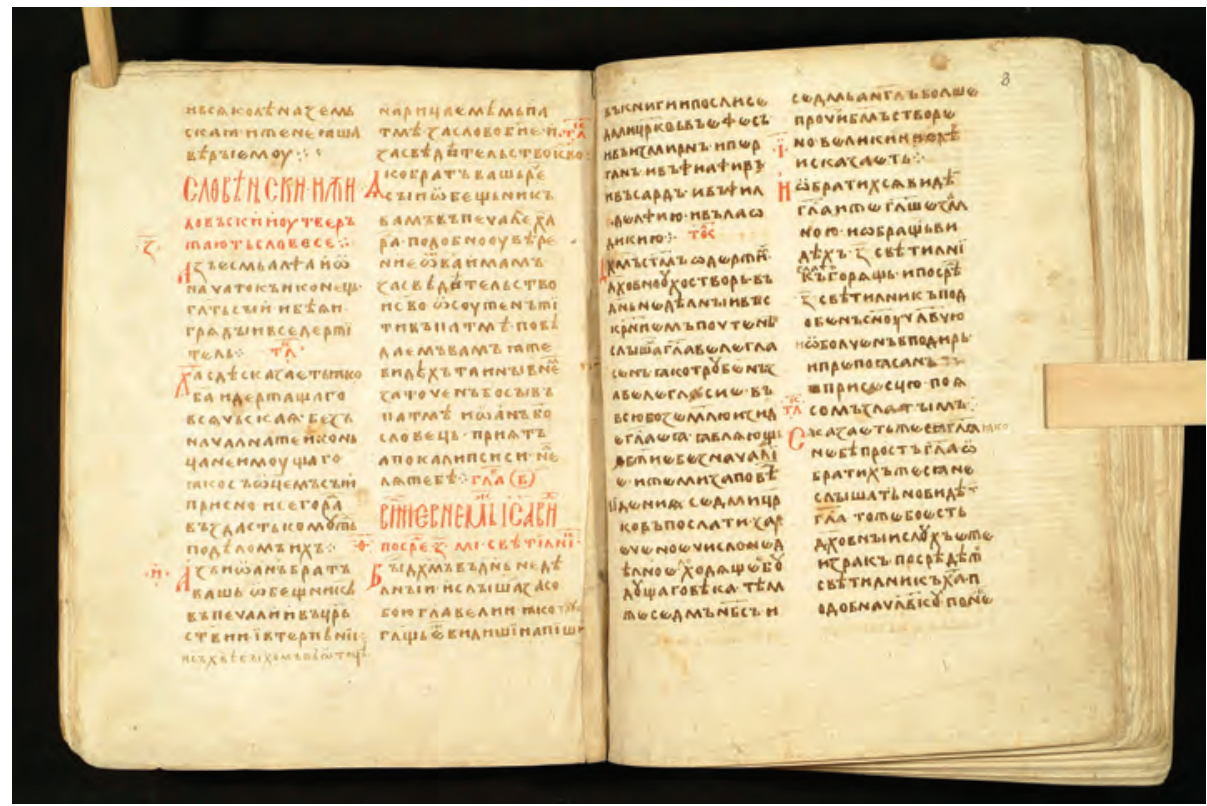

Фиг. 5. Т 119: л. 7об.

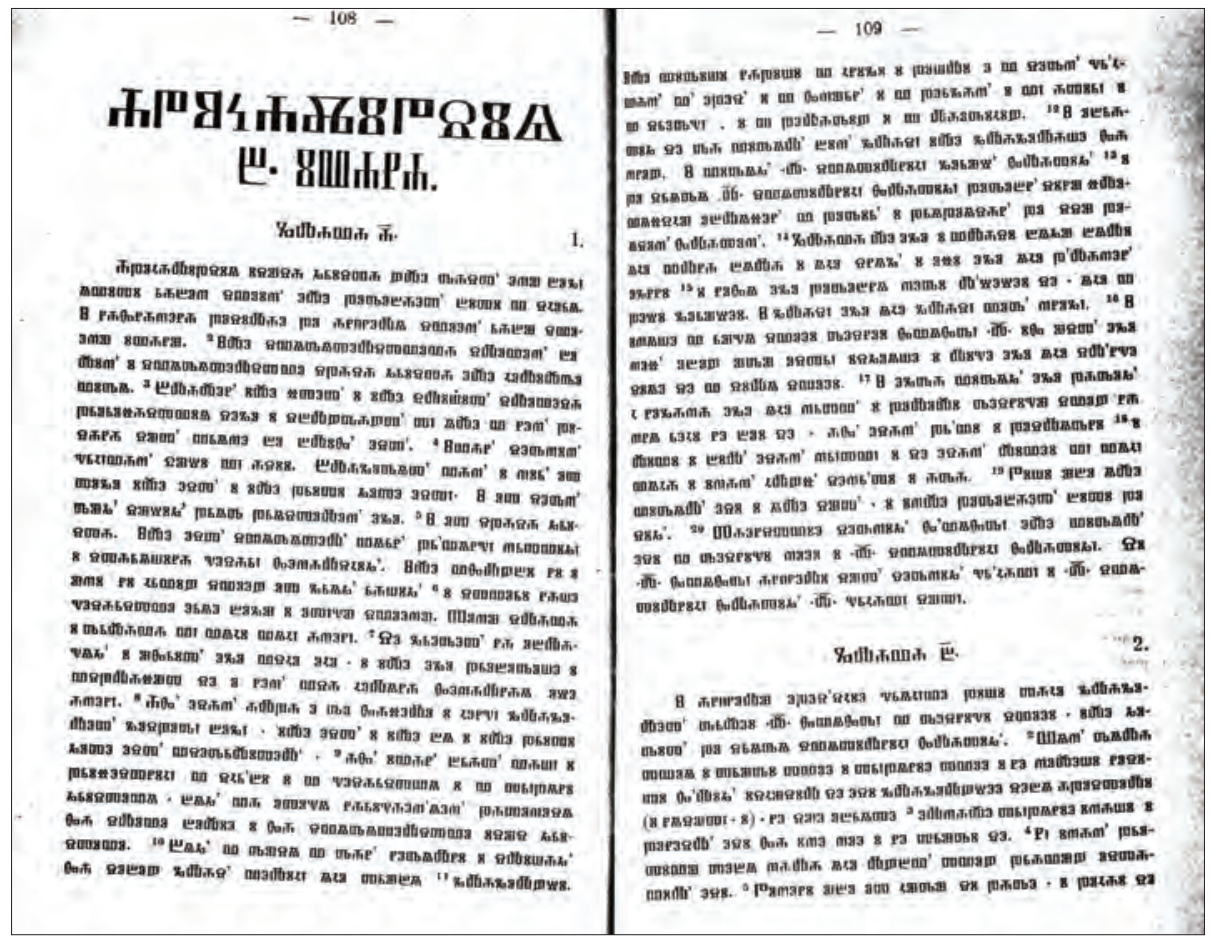

Фиг. 6. I. Berčıć, Ulomci svetoga pisma... 140. 


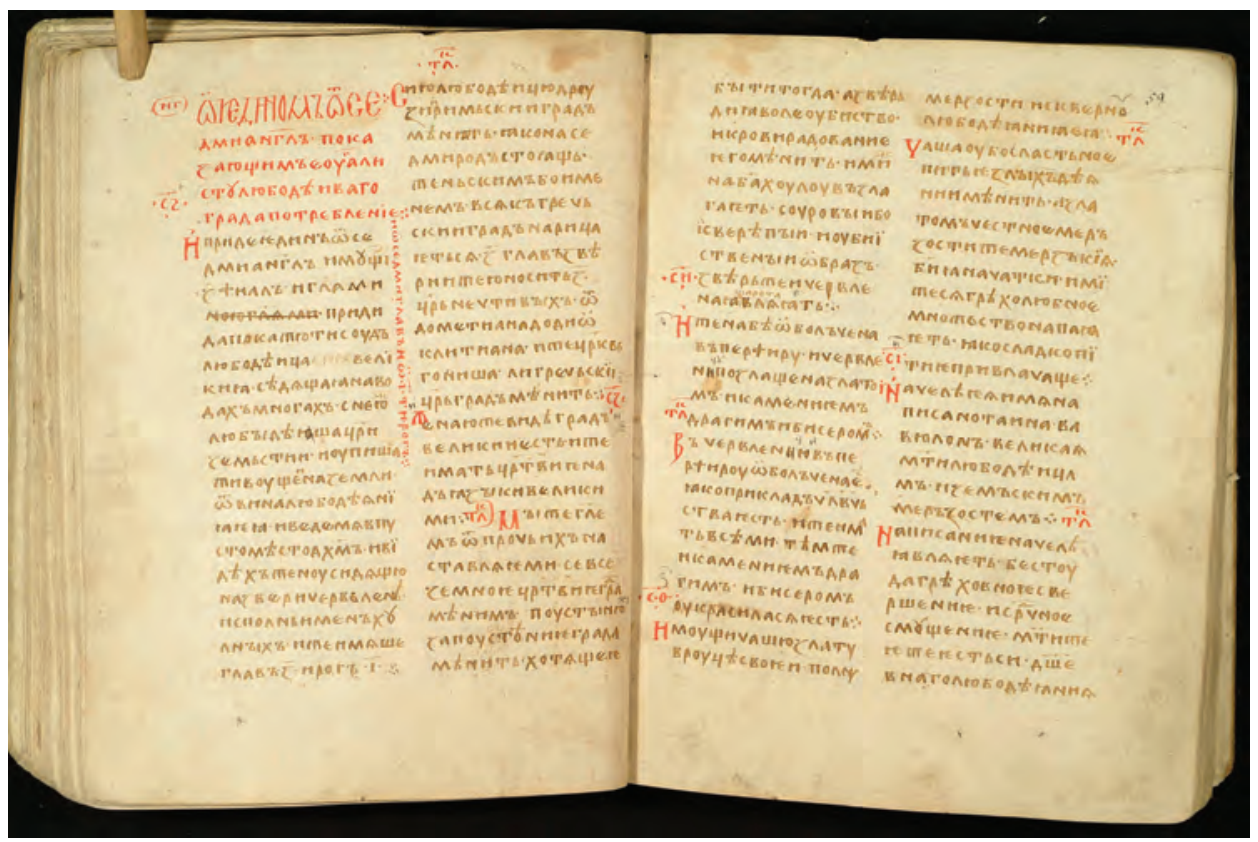

Фиг. 7. Т 119: л. 58о6-59.

Фиг. 8. NB101: Апокалипсис толковый, сербский, XVI в., $220 б$.

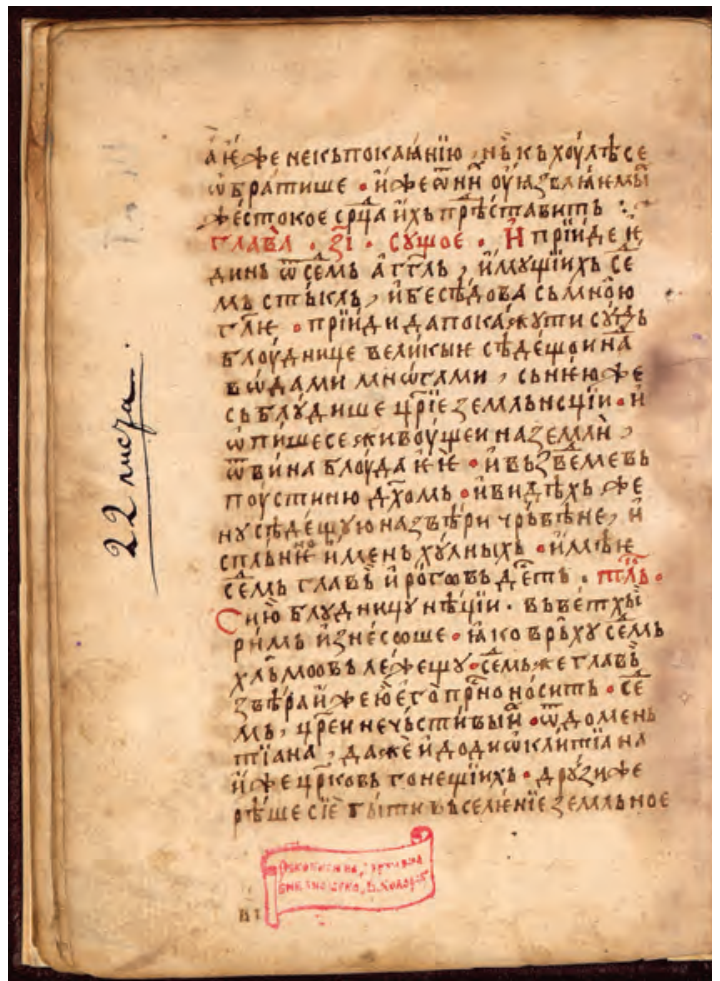




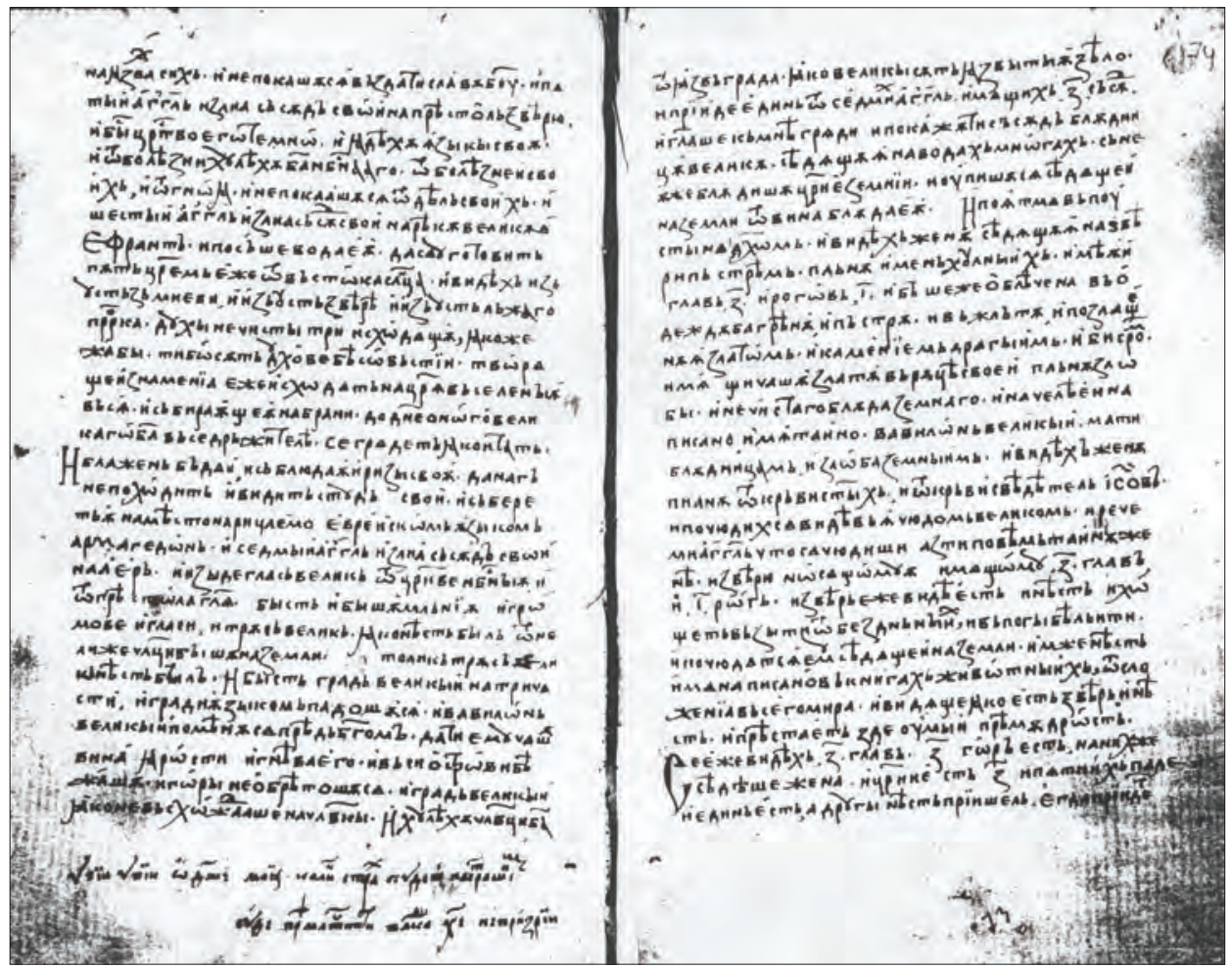

Фиг. 9. MSOC 43: Апокалипсис, без толкований, болгарский, XIV в., 73об-74. 